\title{
Integrins within the Tumor Microenvironment: Biological Functions and Advances in
} Therapeutic Targeting

\author{
Kevin Dzobo ${ }^{1,2^{*}}$
}

\begin{abstract}
${ }^{1}$ International Centre for Genetic Engineering and Biotechnology (ICGEB), Cape Town Component, Wernher and Beit Building (South), UCT Medical Campus, Anzio Road, Observatory 7925, Cape Town, South Africa

${ }^{2}$ Division of Medical Biochemistry and Institute of Infectious Disease and Molecular Medicine, Department of Integrative Biomedical Sciences, Faculty of Health Sciences, University of Cape Town, Cape Town, South Africa

Correspondence: kdzobosnr@yahoo.com; Tel: +27 842953708
\end{abstract}

\begin{abstract}
Many cellular functions important for tumor initiation and progression are mediated by members of the integrin family, a diverse family of cell adhesion receptors. With recent studies emphasising on the role of the tumor microenvironment (TME) in tumor initiation and progression, it is not surprising that a lot of attention is being given to integrins. Several integrins are under trial with many demonstrating appealing activity in patients with different cancers. A deeper knowledge of the functions of integrins within the tumor microenvironment is still required, and might lead to better inhibitors being discovered. Integrin expression is commonly dysregulated in many tumors with integrins playing key roles in signaling as well as promotion of tumor cell invasion and migration. This review report new data on the differential expression of integrins within solid tumors using two publicly available resources: The Cancer Genomic Atlas (TCGA) and Gene Expression Profiling Interactive Analysis (GEPIA). In this analysis, I investigated the expression of integrin alpha 2 (ITGa2), ITGa3, ITG $\beta 4$ and ITG $\beta 6$ in tumor tissues versus adjacent normal tissues. This analysis showed that integrins were differentially expressed in cervical squamous cell carcinoma (CESC), head and neck squamous cell carcinoma (HNSC), esophageal carcinoma (ESCA) and lung adenocarcinoma (LUAD). This analysis showed that ITGa2 and ITG $\beta 6$ expression are upregulated in CESC and ESCA, ITGa3 is upregulated in HNSC and ESCA whilst ITG $\beta 4$ is highly expressed in CESC, HNSC, ESCA and LUAD tumor tissues compared to adjacent normal tissues. Integrins also play a major role in adhesion of circulating tumor cells to new sites and the resulting formation of secondary tumors. Furthermore, integrins have demonstrated the ability to promoting stem cell-like properties in tumor cells as well as drug resistance. Anti-integrin therapies rely heavily on the doses or concentrations used as these determine whether the drugs act as antagonists or as integrin agonists. This review offers the latest synthesis in terms of current knowledge of integrins functions within the tumor microenvironment and potential targets for different cancers.
\end{abstract}

Keywords: Integrins, Tumor Microenvironment, Drug Resistance, Migration, Metastasis, Solid Tumors, The Cancer Genome Atlas, Gene Expression, Computational Biology, Therapeutic Targeting 


\subsection{Introduction}

Tumorigenesis involves the transformation of normal cells into cancer cells via mechanisms that include activation of many signaling cascades. Several studies have shown that integrins are directly involved in tumor initiation and progression via influencing cancer cell proliferation, migration, invasion and survival as well as partaking in cellular signaling [1, 2]. Most studies on integrins have focussed on their role in cellular migration and invasive behaviour. This is mostly due to integrins binding to extracellular matrix (ECM) proteins and aiding in creating traction needed by cells for migration and invasion. In addition, several tumor microenvironment (TME) components including biological molecules such as growth factors and proteases owe their localisation to certain regions to integrins [3, 4]. Thus, integrins can influence cellular proliferation and signaling through 'capturing' growth factors and proteases in certain regions of the TME $[5,6]$. In cancer, integrins play a significant role in controlling cellular growth through binding to ECM proteins such as collagens and fibronectin and relay extracellular signals into the cell to affect gene expression [7-9]. It is important to point out that integrins relay both pro- and anti-tumorigenic signals, with the balance determining tumor growth and inhibition. Advances in TME biology have revealed that integrins, bound to ECM proteins or not, influence tumor growth via influence on cancer cell stemness as well as chemoresistance [10,11]. Understanding the behavior of integrins in normal tissues and cancer has huge implications for their therapeutic targeting.

Beside integrins found on cancer cells, integrins are also present on cells associated with tumors and play a great role in influencing stromal cell-tumour cell interactions [12-14]. These stromal cells range from cancer associated-fibroblasts (CAFs), -macrophages (CAMs), -endothelial cells (CANs) as well as pericytes [15-18]. Most of these stromal cells are directly linked to processes occurring during tumor development and metastasis such as inflammation, angiogenesis and desmoplasia [19-21]. Integrins traverse the lipid bilayer and are the link between the extracellular space and the cytoplasm [22, 23]. Integrins relay extracellular cues through receptors for growth factors and cytokines and thus promote cellular signaling. Being present in both cancer cells and stromal cells, integrins influence tumor development as well as metastasis. New findings show that specific integrins are required by certain growth factors and oncogenes during tumor initiation and growth $[5,6]$. This makes it critical to delineate the crosstalk between integrins and growth factors and oncogenes during drug development. To date, several studies both preclinical and clinical trials have been done using integrin inhibitors and these have demonstrated 
various levels of efficacy at blocking tumor progression [24, 25]. In addition, integrin inhibitors have shown little or no known side effects in some cancer patients [26-28]. The success demonstrated with integrin inhibitors must be augmented by further research into the role of integrins in different cancers as well as in tumor development and growth.

\subsection{Literature Search Methodology}

A search for literature material was done on PubMed and MEDLINE databases until August 2020 for published articles with the following keywords: integrins, tumor microenvironment, gene expression, solid tumors, signaling, growth factors, angiogenesis and metastasis. Language of communication was set to English and full articles were included (Figure 1). A total of 1106 articles were used and with the aid of the criteria as shown in Figure 1, a final total of 190 articles were obtained. The methodology enabled the synthesis of the review on integrins as key players in cellular processes and signaling and their possible therapeutic targeting using different therapies. Several well written articles by a lot of authors were not cited due to limitations on length and 1 humbly apologize for those not cited.

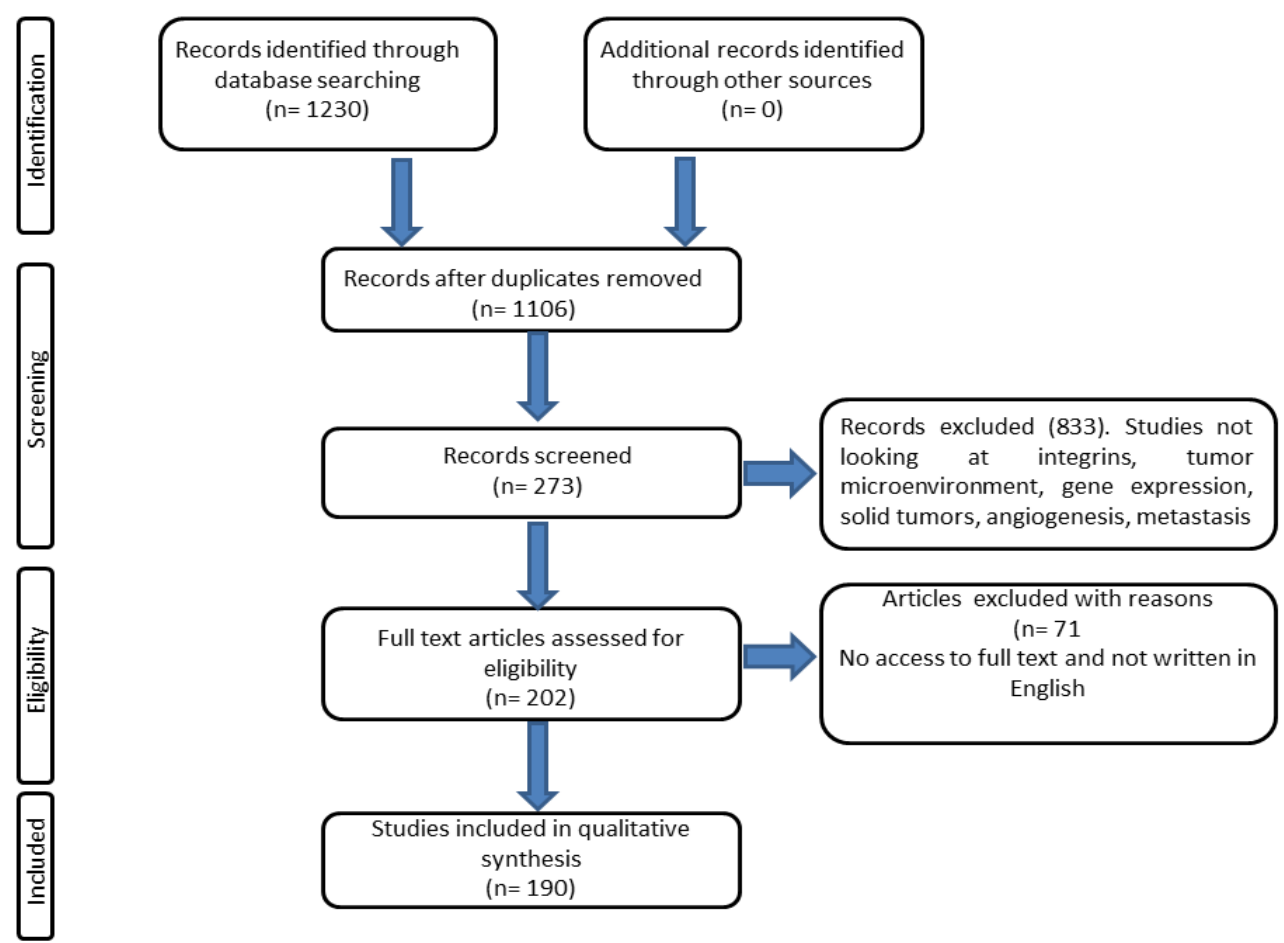

Figure 1. Selection of studies included in the qualitative synthesis of the review manuscript. 


\subsection{Integrin Biological Properties}

Integrins are receptors that traverse the lipid bilayer of the cell membranes and their main function is to relay extracellular cues to cells by binding to the ECM and other immunoglobulin molecules (Figure 2) [23, 29-31]. A minimum of 24 different heterodimer combinations from 18 $\alpha$-subunits and $8 \beta$-subunits are formed. Each combination of $\alpha$ and $\beta$ subunits specifically bind to certain ECM proteins and immunoglobulin molecules [23, 31]. The formation of the integrins dimers occur in the endoplasmic reticulum with post-translational changes occurring in the Golgi apparatus before the inactive integrins are transferred to the cell surface [32]. Different cells express different integrins and this greatly influence adhesion to different surfaces as well as ability to migrate $[20,23]$. The recognition and binding of integrins to their respective ligands may be influenced by the specific sequence on the ligand. For example, integrins $\alpha \mathrm{v}$ and $\alpha 5 \beta 1$ recognize and bind to ligands with the RGD sequence [33]. Furthermore, integrin $\alpha 4 \beta 1$ recognizes and binds to the REDV and EILDV adhesive sequences on several ECM proteins $[34,35]$. Adhesion to the ECM results in integrins forming focal adhesions whish are clusters of integrins and signaling molecules and proteins $[36,37]$. Studies done in two-dimensional (2-D) and 3-D report different compositions of focal adhesions for the same cells [38, 39]. Integrins are able to cluster and therefore activate kinases within focal adhesions such as focal adhesion kinases and Src family kinases [40-42]. In addition, integrins are able to couple the cytoskeleton and the ECM through recruiting several proteins such as $\alpha$-actin and tensin [43, 44]. Together with parvin and PINCH, integrins are able to form large platforms that interact with actin and several signaling cascades $[45,46]$. A family of transmembrane proteins known as tetraspanins cross the cell membrane four times has been shown to form complexes through interaction with several proteins including integrins [47, 48]. Integrins and several of these proteins involved in focal adhesions and other complexes are under investigation as possible target for therapies in many diseases. In addition, oncogene or growth factor-induced signaling may influence integrin binding affinity, contributing to disease states and progression $[49,50]$. 


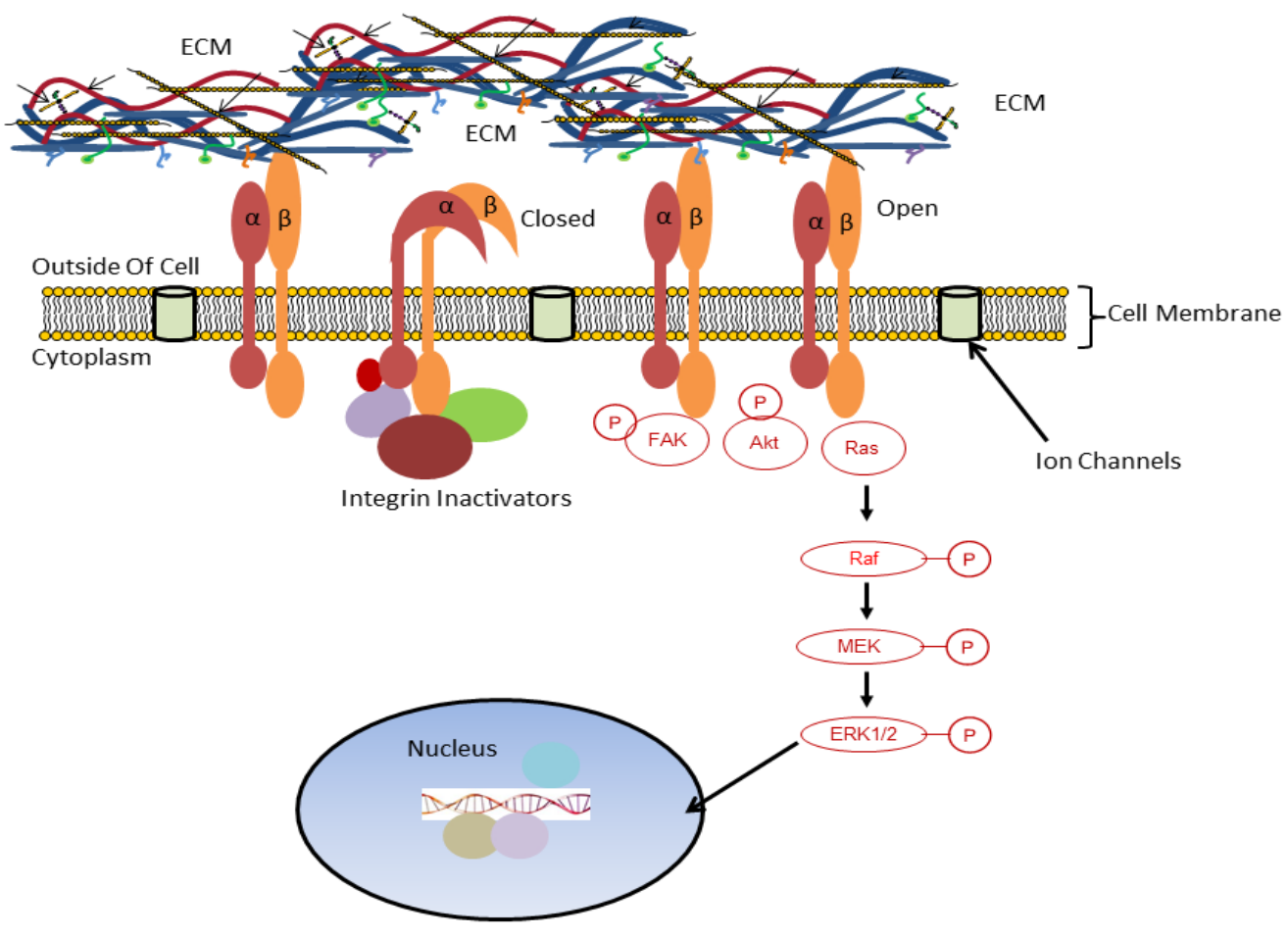

Figure 2. Integrins can have open and closed configurations that influence adhesions to the ECM. The classic outside-in integrin signaling involves integrins binding to the ECM and activation of several intracellular signaling cascades including the Ras-MEK-ERK signaling. The translocation of phosphorylated ERK1/2 molecules to the nucleus results in expression of genes involved in cellular proliferation, migration and survival. Figure was adapted from Dzobo and colleagues $[3,51]$

\subsection{Integrin Contribution to Tumorigenesis}

Several pieces of evidence have shown that integrins contribute toward cancer growth and progression (Figure 3). With many cancers starting in epithelial cells, integrins expressed by these cells play key roles during cancer growth and progression. Integrins increase cellular signaling via interactions with FAK, PI3K-Akt and the MEK-ERK pathways [3, 4]. In addition, stromal cells including caner-associated fibroblasts synthesize increased amounts of ECM proteins and these display enhanced interaction with integrins. Several reports show that integrins are also involved in metastasis and the priming and colonization of new sites for secondary tumors to form. Furthermore, cancer therapy has been shown to induce integrins expression leading to drug resistance. 


\begin{tabular}{|c|c|}
\hline $\begin{array}{l}\text { Tumorigenesis } \\
\text { - Several integrins are linked with } \\
\text { tumorigenesis and expression of } \\
\text { oncogenes. } \\
\text { - Integrins participate in increased } \\
\text { cancer cell signaling } \\
\text { - Linked to desmoplasia }\end{array}$ & $\begin{array}{l}\text { Movement and Invasiness } \\
\text { Enhanced integrin trafficking linked } \\
\text { to tumor cell migration, MMPs } \\
\text { activation and EMT } \\
\text { - Enhanced integrin-ECM interaction } \\
\text { linked to tumor cell invasion and } \\
\text { increased signaling }\end{array}$ \\
\hline $\begin{array}{l}\text { Extravasation and Metastasis } \\
\text { - Unbound integrins support } \\
\text { circulating tumor cells and CSCs } \\
\text { Integrins support and take part } \\
\text { during extravasation } \\
\text { - Reactivation of tumor cells from } \\
\text { dormancy involves integrin signaling }\end{array}$ & $\begin{array}{l}\text { Chemo- and Radio-resistance } \\
\text { - Integrin-ECM interactions reduce } \\
\text { drug flow } \\
\text { - Integrin expression is induced by } \\
\text { presence of drugs and radiation }\end{array}$ \\
\hline
\end{tabular}

Figure 3. The effect of integrins on different stages of tumor progression. Integrins are involved at every stage of tumor progression starting with tumor initiation to tumor cell migration and invasion, extravasation and metastasis and finally the development of therapy resistance.

\subsection{The Significance of Integrins in Tumorigenesis}

Examples of integrins expressed by epithelial cells include $\alpha 2 \beta 1, \alpha 6 \beta 4$ and $\alpha 3 \beta 1$ and may display dysregulated expression in tumors. Whilst data strongly show these integrins role in cellular attachment to the ECM and the basement membrane, recent data also showed their participation in cellular proliferation, migration and metastatic behaviours [52-54]. Integrins expression has also been shown to change when epithelial cells transform to cancer cells. For example, $\alpha \mathrm{v} \beta 6$ and $\alpha v \beta 3$ integrins are known to be highly upregulated in tumors such as ovarian and colon compared to normal cells [55-58]. In addition, these integrins are also associated with increased metastasis and tumor cell proliferation in ovarian cancer [59, 60]. Several reports also show that some integrins decrease in expression in some tumors. For example, $\alpha 2 \beta 1$ integrin expression is decreased in breast tumors [61-63]. Decreased integrin expression in cancer cells has been linked with invasion and metastatic behavior [64-66]. Several studies have linked integrin expression in tumors to patient survival and disease progression, with integrins $\alpha v \beta 3, \alpha 6 \beta 4$ and $\alpha v \beta 6$ among the most studied. As new data is generated, the picture become clear on which integrins are important in different tumors. McCabe and colleagues demonstrated that $\alpha v \beta 3$ integrin is 
associated with metastatic behaviour of prostate cancer cells to the bone matrix [67]. In addition, the expression of $\alpha v \beta 3$ and $\alpha v \beta 6$ is linked to decreased cervical cancer patients survival $[68,69]$. Integrin $\alpha 5 \beta 1$ expression is associated with metastasis and decreased cancer patient survival in melanoma and lung carcinoma [70-72]. The expression of $\alpha \mathrm{v} \beta 3$ is linked to pancreatic cancer cells metastasizing to the lymph node [73].

\subsection{Bioinformatic Analysis of Integrins' RNA-seq Data}

Increasing data indicate that integrins represent an important component of the tumor microenvironment and thus contribute to several malignant phenotypes. Utilizing the publicly available The Cancer Genomic Atlas ((http://cancergenome.nih.gov), the Gene Expression Profiling Interactive Analysis (http://gepia.cancer-pku.cn) datasets and The Human Protein Atlas (www.proteinatlas.org), below this study evaluated the significance of integrins in solid cancer malignance. Integrin differential expression was evaluated in tumor tissues versus the adjacent normal tissues as well as in relation to patients' overall survival. Messenger RNA expression levels of ITGa2, ITGa3, ITG $\beta 4$ and ITG $\beta 6$ were evaluated in tumor tissues compared to adjacent normal tissues. Expression data was downloaded in October 2020 via the TCGA portal using available web-based tools allowing deep analysis of the integrins expression. Webbased tools available on the GEPIA website were used for analysis of integrins expression within TCGA and GEPIA databases.

\subsection{Statistical Analysis}

GraphPad Prism software (version 6, San Diego, USA) was used for the analysis with both Student's t-test and one way analysis of variance test used to analyse significance of differences. Statistical significance was set at $\mathrm{p}<0.05$.

\subsection{Differential Expression of Integrins in Tumors}

Several pieces of evidence points to integrins contributing to tumor initiation and development of malignant phenotypes, therefore it is important to investigate the significance of integrins in several solid tumors using The Cancer Genomic Atlas dataset. In this analysis, four cancers were used as examples to investigate the relationship between integrin expression and cancer malignance phenotype. The cancers analysed are cervical squamous cell carcinoma (CESC), head 
and neck squamous cell carcinoma (HNSC), esophageal carcinoma (ESCA) and lung adenocarcinoma (LUAD). Expression of integrins in tumor tissues was compared to that in adjacent normal tissues (as a box plot) based on TCGA/GEPIA database.

Bioinformatic analysis showed that ITGa2 expression was significantly upregulated in CESC and ESCA tumor tissues compared to adjacent normal tissues (Figure 4A). The increased ITG $\alpha 2$ expression observed in ESCA was observed in our previous report [20]. Consistent with the above results, 10 out of 11 cervical cancer specimens showed medium to high ITG $\alpha 2$ protein expression based on immunohistochemistry data available at The Human Protein Atlas database. There were no significant differences in ITGa2 expression in HNSC and LUAD tumor tissues compared to adjacent normal tissues (Figure 4A). ITGa3 expression was upregulated in HNSC and ESCA tumor tissues versus adjacent normal tissues whilst there were not significant differences in ITGa3 expression in CESC and LUAD tumor tissues versus normal tissues (Figure 4B). Consistent with the data for HNSC, 3 out of 4 HNSC cancer specimens showed medium to high ITG $\alpha 3$ protein expression based on data available on The Human Protein Atlas database. ITG $\beta 4$ expression was upregulated in CESC, HNSC, ESCA and LUAD tumor tissues compared to adjacent normal tissues (Figure 5A). ITG $\beta 6$ expression was upregulated in CESC and ESCA tumor tissues versus adjacent normal tissues whilst ITG $\beta 6$ expression showed no significant differences in HNSC and LUAD tumor tissues versus adjacent normal tissues (Figure 5B). Consistent with the above, 9 out of 12 CESC cancer specimens showed medium to high ITG $\beta 6$ protein expression based on data available on The Human Protein Atlas database. Together, the above data indicate that integrins are an important part of the tumor microenvironment and contribute to cancer malignant phenotype and the process of tumor development. 
A

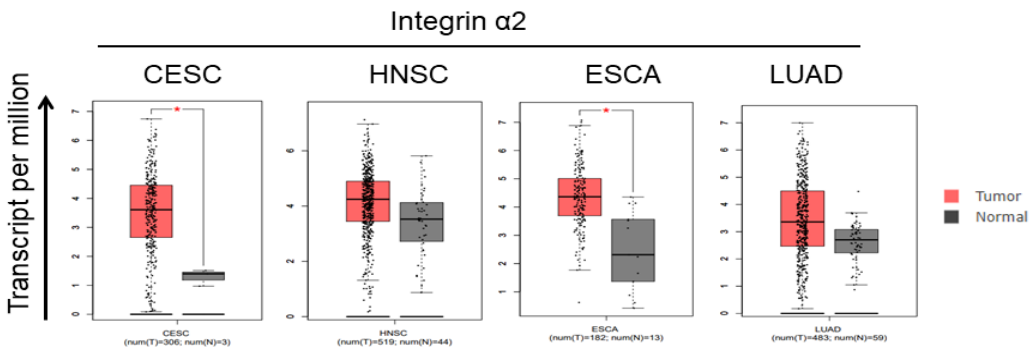

B

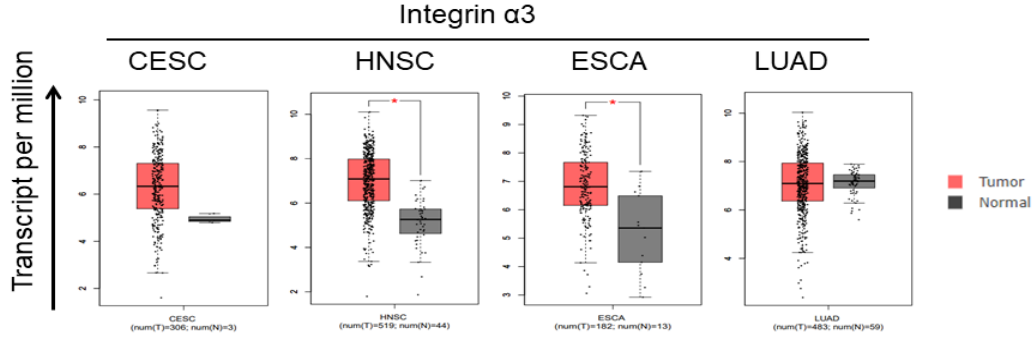

Figure 4. The differential expression of ITGa2 (A) and ITGa3 (B) in cervical squamous cell carcinoma (CESC), Head and Neck squamous cell carcinoma (HNSC), Esophageal carcinoma (ESCA) and Lung adenocarcinoma (LUAD) tumor tissues and adjacent normal tissues (box plot) based on TCGA/GEPIA database. Integrin expression showing significant differences between tumor and normal tissues are shown with $*$ indicated for $\mathrm{p}<0.05$. GEPIA- gene expression profiling interactive analysis; TCGA- The Cancer Genome Atlas.

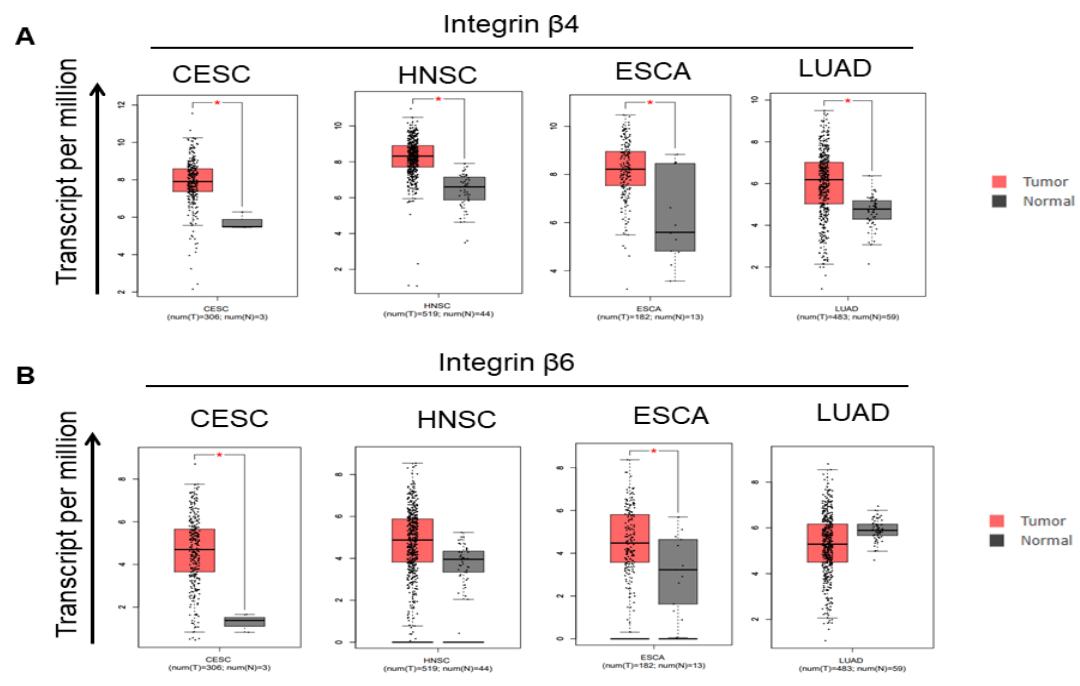

Figure 5. The differential expression of $I T G \beta 4$ (A) and ITG $\beta 6$ (B) in cervical squamous cell carcinoma (CESC), Head and Neck squamous cell carcinoma (HNSC), Esophageal carcinoma (ESCA) and Lung adenocarcinoma (LUAD) tumor tissues and adjacent normal tissues (box plot) based on TCGA/GEPIA database. Integrin expression showing significant differences between tumor and normal tissues are shown with $*$ indicated for $\mathrm{p}<0.05$. GEPIA- gene expression profiling interactive analysis; TCGA- The Cancer Genome Atlas. 


\subsection{Integrin Promotion of Tumor Cell Survival}

Integrins have been shown to act in both a pro- and anti-tumorigenic manner, depending on signals within the tumor microenvironment. Tumor cell-expressed integrins promote cell survival via involvement in proliferation, invasion and metastasis among several processes. In the case of invasion, integrins binding to different ECM proteins generates the needed traction for movement and invasive behavior. Formation of focal adhesions and the involvement of MMPs at the leading edge allow cells to invade new territories and tissues [74]. Several reports however point to the involvement of some integrins in preventing tumor cell migration. For example Kren and colleagues demonstrated that the absence of integrin B1 increased cancer cell metastatic behaviour [75]. Integrins can promote tumor cell survival though participation in several signaling mechanisms whilst integrins have also been shown to play in a role in the process of apoptosis. How integrins behave depends on whether they are free or bound to their ligands. A critical balance is maintained through integrins interacting with ligands and this helps to maintain cell and organs integrity. For example, the binding of integrins to ligands can activate survival pathways such as MEK-ERK, nuclear factor-k $\beta$ (NF-kB) and PI3-K-Akt pathways [3, 4, 76-78]. Interaction of integrins and the ECM upregulates BCL-2 expression in cancer cells [79, 80]. The interaction between integrins and growth factor receptors also play a role in preventing apoptosis in cells [81, 82]. Deletion of integrins genes or inhibition of integrin-mediated signaling has been shown to activate a compensatory upregulation of vascular endothelial growth factor receptor-2 expression, complicating the targeting of integrins in pathological conditions such as cancer [83-85]. Several data show that integrin function in tumors may be context dependent, with data showing that integrins such as $\alpha v \beta 3$ is pro-tumorigenic but can inhibit tumor growth in cancers such as melanoma and glioblastoma [52, 86-88].

A subpopulation of cells known as cancer stem cells (CSCs) that is thought to give rise to all tumor cells present in tumors [89-92]. Several pieces of evidence point to integrins playing a part in tumorigenesis and as markers of CSCs [11, 93]. For example, Asselin-Labat and colleagues demonstrated that stem cell-like cells within the mammary ductal epithelium express $\alpha v \beta 3$ integrin and it can be used a marker of these cells [94]. Vaillant and colleagues revealed that $\beta 3$ integrin as well as WNT1 were both markers of mammary CSCs [95]. Luo and colleagues demonstrated that removal of integrin-associated focal adhesion kinase signaling reduced the number of CSCs in mammary tumors in mice [96]. Samanna and colleagues showed that $\alpha v \beta 3$ expression was linked to tumorigenicity and MMP-2 activity in melanoma cells [97]. Specifically, 
the authors showed that integrins influence the expression of CSCs markers such as CD44 [97].

\subsection{Integrins Contribution towards Tumor-Host cell interactions}

Integrins are also involved in the response of normal cells to the presence of tumor cells. Reports indicate that most cells including fibroblasts, mesenchymal stem cells, pericytes, immune cells and endothelial cells utilise integrins in cellular processes such as migration, angiogenesis and desmoplasia. The targeting of integrins on stromal cells may aid in limiting the 'support' given to tumor cells by normal cells.

Integrins are involved in every stage of tumorigenesis from initiation to metastasis [98]. Several pieces of evidence points to 'leaky' blood vessels in tumors which causes impaired blood flow and drug delivery [99]. In addition, leaky blood vessels are also known to promote fibrosis in tumors [100]. Brooks and colleagues showed that integrin $\alpha \mathrm{v} \beta 3$ was upregulated in chick chorioallantoic membrane and associated to angiogenesis [101]. It has been speculated that integrins may enable the interaction between ECM proteins and angiogenic-associated cells such as endothelial cells within the TME $[102,103]$. Remodelling of the ECM has also been linked to increased integrin binding to degraded ECM proteins such as collagen [104]. Several reports have demonstrated that integrins are important for cellular processes such as migration and angiogenesis [98]. Various compounds or small molecules in addition to genetic manipulation have confirmed the involvement of integrins including $\alpha 2 \beta 1, \alpha 6 \beta 1$ and $\alpha 6 \beta 4[3,4,98]$. Together with growth factor receptors, integrins can relay signals from growth factors to influence angiogenesis in tumors $[101,105,106]$. In elaborate experiments, Friedlander demonstrated that protein factors, basic fibroblast growth factor and tumor necrosis factor- $\alpha$ require the integrin $\alpha v \beta 3$ to induce angiogenesis in corneal [105]. In addition, the same authors also showed that vascular endothelial growth factor and transforming growth factor- $\alpha$ induced angiogenesis through interaction with integrin $\alpha \mathrm{v} \beta 5$ [105]. Most importantly, integrins can bring together signals from both the ECM and several growth factors in order to influence cellular processes.

Several cells have been shown to play a role in angiogenesis and these include vascular smooth muscle cells and pericytes. Blood vessel maturation for example requires pericytes and smooth muscle cells [107-110]. Most blood vessels found within the TME are abnormal and leaky, leading to less oxygen reaching all cells. Interaction between pericytes and endothelial cells is via 
integrin $\alpha 4 \beta 1$ and vascular cell adhesion molecule 1 (VCAM1) for example [111]. This may lead to blood vessel formation and stability [111]. The branching of blood vessels within tumors also require pericytes involvement through integrin binding [112]. Thus a combination of therapeutic targeting tumor cells as well as therapeutics targeting angiogenesis and its associated cells to bring about blood vessel normalization may provide a synergistic and durable effect in cancer treatment [113-115]. Indeed, it has been suggested that treatment with anti-angiogenic therapeutics first before cytotoxic drugs may be better at treating cancer [115]. Thus today, vascular normalization is part of cancer therapies in many settings and clinics.

One of the observed hallmarks of desmoplasia in tumors is the synthesis and deposition of large amount of ECM proteins such as collagens. Increased collagen within the TME means increased integrin signaling allowing promotion of cancer cell survival and resistance to therapy [116]. Integrins on both cancer cells and stromal cells contribute towards cancer cell growth via activation of signaling that promote cancer cell growth. For example, Zhu and colleagues demonstrated that in non-small cell lung carcinoma several integrins including $\alpha 11$ is necessary for cancer cell growth [117]. Integrin $\alpha 11$ was instrumental in inducing insulin-like growth factor 2 release in human non-small-cell lung cancer cells [117]. Integrins inhibitors must therefore target both cancer cells and stromal cells for effective and durable cancer treatment.

Several pieces of evidence have shown that bone marrow-derived cells from the bone marrow are found within solid tumors $[21,118,119]$. Once in the TME, these bone marrow-derived cells can exhibit contrasting effects on cancer cells with some cells having anti-tumorigenic effects whilst others have tumor promoting effects. For example, infiltrating macrophages expressing integrin $\alpha v \beta 3$ are able to have anti-tumorigenic effects [120]. In addition, bone marrow derived cells with no functional integrin $\beta 3$ are not found within tumor sites and cannot therefore promote angiogenesis [121]. Jin and colleagues demonstrated that cells attracted to tumors including endothelial cells require integrin $\alpha 4 \beta 1$ [122]. Integrin $\alpha 4 \beta 1$ is needed for the binding of bone marrow derived cells to the endothelium within TME [123]. In terms of targeting integrins needed for the homing of bone marrow-derived cells to tumors, a balance must be maintained between anti-tumorigenic and pro-tumorigenic effects. 
Tumor metastasis has been associated with the interaction between cancer cells and platelets. For example, Mammadova-Bach and colleagues demonstrated that integrin $\alpha 6 \beta 1$ on platelets promotes metastasis via binding to lung cancer cell-derived ADAM9 [124]. In addition, Gay and colleagues showed that platelets can alter tumor cell characteristics and promote metastasis [125]. Furthermore, fibrinogen can behave as act as a connection between platelets and cancer cells via attaching to integrins on both cells and this allows cancer cells to be associated with blood vessels $[126,127]$. Metastasis to the bone marrow and the lungs is also made possible via interaction between cancer cells and platelets [127, 128]. Trikha and colleagues demonstrated that the combined inhibition of integrins on both cancer cells and platelets enhances the antitumorigenic of the inhibitors compared to inhibition of integrins on tumor cells [129].

\subsection{Integrin Crosstalk with Other Receptors}

Cooperation between integrins and oncogenes in promoting tumor growth has been noted. Guo and colleagues demonstrated that integrin $\alpha 6 \beta 4$ cooperates with ERBB2 and enhances tumor initiation and invasion in breast cancer [130]. There is also an association between integrin $\beta 1$ and polyoma middle $\mathrm{T}$ oncoproteins in driving breast cancer [131]. Some lung tumors require the involvement of integrin $\alpha 1$ for the initiation and growth of the tumors [132]. The Src oncogene activity has been shown to be enhanced via its interaction with integrin $\alpha 4 \beta 3$ [133]. These several pieces of evidence demonstrate that integrin signaling is involved in enhancing the pro-tumorigenic effect of many oncogenes.

Tumor development and growth studies have shown that integrins play crucial roles through interactions with growth factors as well as cytokines. The involvement of integrins in adhesion, migration and invasion of tumor cells is well documented, however integrins have been shown to play more roles including enhancing angiogenesis and signaling. Interaction between integrins and growth factors and cytokines is not always pro-tumorigenic, with several pieces of data showing that integrins interactions can be anti-tumorigenic [134]. The interaction of integrins and growth factors is likely to influence signaling pathways involving kinases to enhance tumor cell survival and invasiveness $[135,136]$. Growth factors can also influence integrin internalisation and activity and vice-versa [137-142]. 
The cooperation between integrins and growth factors and their receptors has been noted for its role in tumor development, growth and eventual metastasis in several cancers. Involvement of growth factors including the epidermal growth factor receptor family can be through increased expression or activation leading to oncogenic signaling in tumor cells. For example, enhanced expression of ERBB2, also known as v-erb-b2 avian erythroblastic leukemia viral oncogene homolog 2 , and its receptors is observed in several cancers including breast and nasopharyngeal carcinoma [143-146]. Cooperation between integrins and the EGF receptor family has been reported in breast cancer. Guo and co-workers demonstrated that integrin $\alpha 6 \beta 4$ cooperates with ErbB2 signaling in breast cancer to promote tumor development and growth [130]. This cooperation also promoted invasion of tumor cells [130]. Furthermore, the authors showed that this cooperation causes the activation of the signal transducer and activator of transcription (STAT3) signaling, a signaling pathway known to cause increased cellular proliferation [130]. The targeting of both $\alpha 6 \beta 4$ integrin and the ERBB2 may produce a synergistic therapeutic effect [130]. The interaction between integrins, growth factors and ECM proteins such as collagen and glycoproteins such a vitronectin can promote cancer cell migration and metastasis [147-149]. Integrin $\alpha \mathrm{v} \beta 5$ for example interacts with EGF and vitronectin to promote tumor cell migration [147-149]. Pouliot and colleagues demonstrated that EGF cooperates with $\alpha 3 \beta 1$ and the ECM protein laminin for example to promote migration of human colon carcinoma cells [150]. Another important study demonstrated that integrins $\alpha 1 \beta 1$ and $\alpha 2 \beta 1$ interact with EGF to promote the invasive behavior of hepatocarcinoma cells in a fibrotic microenvironment [151].

The cooperation between integrins and the hepatocyte growth factor (HGF) receptor, MET, has been implicated in tumor initiation and invasion. Bertotti and colleagues demonstrated that Integrin $\beta 4$ cooperates with HGF receptor, MET, to promote fibroblasts transformation and the eventual involvement of such transformed fibroblasts in tumorigenesis [152]. In another study, the same authors also showed that through induction of integrin $\beta 4$ phosphorylation, MET signaling upregulates anchorage-independent growth [153]. Reports show that integrin $\alpha \mathrm{v} \beta 5$ can regulates the expression of genes induced by HGF and involved in cell invasion [154]. Overall, HGF-MET signaling cascade involvement in tumorigenesis is dependent on cooperation with integrins. Another growth factor shown to be involved in promoting tumorigenesis is transforming growth factor (TGF- $\beta$ ). For example, TGF- $\beta$ has been shown to play a key in epithelial-mesenchymal transition (EMT) leading to increased tumor cell movement and invasiveness [155-157]. Integrins such as $\alpha v \beta 6$ and $\alpha v \beta 8$ play a key role in the activation of TGF$\beta$ signaling through binding to the RGD sequence of the latency-associated peptide of TGF- $\beta 1$ 
[158-161]. Marsh and colleagues demonstrated that enhanced integrin $\alpha \mathrm{v} \beta 6$ expression together with increased TGF- $\beta$ activation leads to aggressive disease in basal cell carcinoma [162]. Immunohistochemical studies and transcriptional activation experiments confirmed that $\alpha \mathrm{v} \beta 6$ activates the TGF- $\beta$ signaling cascade in vivo and EMT leading to tumor growth [163, 164]. TGF- $\beta$ signaling together with integrin $\alpha \mathrm{v} \beta 3$ activates EMT process in epithelial cells $[165,166]$. Our study demonstrated that both tumor cells and stromal cells secrete TGF- $\beta$, and it is plausible that the crosstalk between TGF- $\beta$ and integrins play a key role in tumor growth and progression [21].

Integrins cooperation with growth factor occurs between tumor cells and stromal cells as well. For example, endothelial cell migration and proliferation require integrin and growth factor interactions during angiogenesis. Several reports have linked specific integrins to specific growth factors during angiogenesis [101, 167-169]. Fibroblast growth factor receptor is known to interact with integrin $\alpha \mathrm{v} \beta 3$ leading to the phosphorylation of serine residues in $\operatorname{Raf}[170,171]$. The resulting complex known as MAP3K5 complex causes inhibition of the apoptotic pathway thus protects endothelial cells from apoptosis [172]. In addition, VEGFR2 has been shown to interact with integrin $\alpha \mathrm{v} \beta 3$ and $\alpha \mathrm{v} \beta 5$ to inhibit apoptosis by regulating the Ras-ERK pathway [170]. VEGFR2 also interacts with integrin $\alpha \mathrm{v}$ in endothelial cells to increase angiogenesis [172174]. Increased tumor cell proliferation is observed when activated $\alpha \mathrm{v} \beta 3$ causes secretion of growth factor VEGF [175]. Nikolopoulos and colleagues demonstrated that integrin $\beta 4$ cooperates with fibroblasts growth factor to induce angiogenesis and increased tumor growth [176]. CXCR4 is expressed by both tumor and stromal cells and its increased expression has been associated with increased expression of several integrins [177-179].

\subsection{Targeting Integrins in Cancer Therapy}

Integrins are appealing therapeutic targets for cancer therapy due to their increased expression in several cancers and cooperation with growth factors during tumor development and metastasis. Furthermore, integrins have been shown to play a key role in the development of drug resistance. Our work and that of others have specifically shown the involvement of integrins and their ligands in cancer cell drug resistance [11, 20, 21, 180, 181]. Several in vitro and animal studies have shown that inhibition of integrin function through the use of antagonists is effective at blocking tumor development and metastasis. Integrin function blockage can affect 
both tumor cells and stromal cells [98, 182-184]. For example, cilengitide is currently under Phase 3 clinical trial for the treatment of glioblastoma. Cilengitide is also under study for its effectiveness against lung, glioblastoma and prostate cancer [185-188]. A monoclonal antibody, LM609 or its humanized version Etaracizumab, demonstrated anti-angiogenic activity in many studies including breast cancer studies [189]. Mulgrew and colleagues demonstrated that blocking $\alpha v \beta 3$ with the monoclonal antibody Abegrin can result in inhibition of tumor growth [190]. Integrin $\alpha \mathrm{v} \beta 3$ is one of the major integrins expressed by osteoclasts and its inhibition through the use of monoclonal antibody Vitaxin ${ }^{\circledR}$, blocks bone metastasis [191]. Vitaxin also demonstrated efficacy in patients with renal cancer and other solid tumors [192, 193]. Trikha and colleagues and Chen and co-workers demonstrated that the monoclonal antibody CNTO95 have anti-angiogenic effects and can block cell signaling and invasion in breast cancer cells, respectively $[194,195]$. The amount of integrin antagonists used in studies is very important as some studies demonstrated that certain concentrations of doses of antagonists can act as integrin agonist fashion [196-198]. Most anti-angiogenic drugs increase tumor perfusion which is linked to better drug delivery in tumors [199, 200]. Thus, several studies have demonstrated that antiangiogenic therapy targeting integrins works well when combined with chemotherapy. In addition, integrin targeting affects not only tumor cells but several stromal cells within the TME. Integrin $\beta 1$ via interaction with several signaling cascades including the Akt and the FAK pathways has been shown to play key roles in development of lung cancer and head and neck drug resistance [201, 202]. Hirata and colleagues demonstrated that enhanced integrin $\beta 1$ signaling via interaction with FAK was associated with resistance to the highly selective inhibitor of B-Raf, PLX4720 [203].

Vascularized tumors including glioblastomas demonstrate increased expression of integrins such as integrin $\alpha v \beta 3$ and $\beta 8$ [204-206]. In most cases, these tumors are aggressive and exhibit low patient survival making the development of integrin antagonists necessary to increase patient survival [207-209]. It has been shown that tumor microenvironment is a crucial determinant of therapy effectiveness, thus targeting angiogenesis and stromal integrins is a viable option $[15,16$, 20, 21, 89, 206, 207]. For example, esophageal carcinoma abundantly express ECM proteins some of which are ligands for several integrins and thus can influence cancer cell survival and migration [20]. Thus, it is possible to target integrins such as $\alpha 2 \beta 1$ as the ECM ligands including fibronectin and collagen are abundantly expressed in esophageal cancer [3, 4, 20, 21]. Several clinical trials have been performed or under way to determine the effectiveness of integrin targeting in different cancers [186-188]. 
Park and colleagues demonstrated that an integrin $\beta 1$ inhibitory, AIIB2, was able to reduce breast cancer survival through activation of apoptosis [210]. In yet another study, Bhaskar and colleagues showed that chimeric integrin $\alpha 5 \beta 1$ antibody, Volociximab, displayed anti-angiogenic activity and inhibited tumor growth [211]. Khalili and colleagues also showed that peptide inhibitor of integrin $\alpha 5 \beta 1$, ATN-161, was able to inhibit cancer growth as well as metastasis [212]. The same peptide inhibitor, ATN-161, together with commonly used drug fluorouracil were able to inhibit colon metastasis to the liver [213]. A small molecule integrin $\alpha v \beta 3$ inhibitor S247 was able to breast cancer cell metastasis to the bone [214]. The same effect was demonstrated by another integrin $\alpha \mathrm{v} \beta 3$ inhibitor PSK1404 [215]. S137 and S247 are RGD peptide mimetics and have been shown to inhibit metastasis [216]. 6.3G9 is an integrin $\alpha v \beta 6$ antibody that has been shown to have anti-cancer activity in pharyngeal carcinoma cells [163].

One major challenge associated with targeting integrins and its associated cellular processes such as angiogenesis is the lack of validated biomarkers. Several markers such as serum levels of fibroblast growth factor and vascular endothelial growth factor have been suggested to indicate the efficacy of anti-integrin therapy. However, few or no reports have shown the efficacy of such biomarkers in the clinical setting. Current investigations involving coupling integrin antagonists and radionuclides aim to identify newly formed blood vessels in tumors [217]. In addition, newly formed vessels can also be identified via the use of ultrasound with microbubbles as shown for $\alpha \mathrm{v}$-integrins by Leong-Poi and colleagues [218]. Angiogenesis in tumors can also be detected via the use of ${ }^{18}$ F-labeled PEGylated RGD peptide [219]. The above noted examples and others demonstrate the potential use of labelled integrins antagonists as both treatment options and as diagnostic tools in cancer therapy. Furthermore, therapeutics targeting integrins can also be used to deliver drugs and proapoptotic peptides to tumor cells. For example, Hood and co-workers targeted integrin $\alpha \mathrm{v} \beta 3$ with a nanoparticle whilst delivering mutant RAF1 gene to blood vessels within the tumor, leading to tumor shrinkage [81]. Nanoparticles can also be coupled to drugs such as doxorubicin and be able to target integrins and tumor vasculature [220].

\subsection{Conclusion}

Whilst most cells within the human body express integrins, those expressed by tumor cells and stromal cells within the TME are involved in several processes along the tumorigenic path. 
Importantly, integrins have been shown to partake in promoting tumor cell proliferation, survival, migration as well as metastasis. Recent studies have demonstrated the role played by both bound and unbound integrins with both integrins playing a role in promoting tumor cell survival and metastasis. These newly discovered properties of integrins are important in drug discovery and integrin targeting. Integrins also cooperates with growth factors in promoting tumorigenesis and formation of secondary tumors. Furthermore, integrin investigations must be coupled to ECM studies as both play a role in tumor cell response to therapy and development of therapy resistance.

\section{Acknowledgements: Not Applicable.}

Conflict of interest: The author declare no conflict of interest

\section{Definitions}

Endothelial to mesenchymal transition - Transformation of endothelial cells into mesenchymal cells.

Epithelial to mesenchymal transition - Transformation of epithelial cells into mesenchymal cells.

Extracellular Matrix - Extracellular fibrous proteins synthesized by both tumor and stromal cells such as macrophages, fibroblasts, mesenchymal stem cells and pericytes. The ECM's main functions are to provide structural support and biochemical cues to surrounding cells. Within the ECM are biomolecules such as growth factors, cytokines and chemokines and these in turn influence tumor and stromal cell behaviour.

Desmoplasia - Tissue response to injury or insult causing synthesis of huge amounts of ECM resulting in fibrosis.

Matrix Metalloproteases - Zinc-containing protease enzymes that degrade ECM proteins. 
Tumor microenvironment - Cellular and non-cellular components of the environment surrounding cancer cells. Cells would normally include both resident and infiltrating stromal cells such as cancer-associated fibroblasts, pericytes and immune cells

Stromal cells- Cells within the TME that actively support tumor growth.

\section{References}

1. Mitra, S. K.; Schlaepfer, D. D., Integrin-regulated FAK-Src signaling in normal and cancer cells. Current opinion in cell biology 2006, 18, (5), 516-523.

2. Guo, W.; Giancotti, F. G., Integrin signalling during tumour progression. Nature reviews Molecular cell biology 2004, 5, (10), 816-826.

3. Dzobo, K.; Leaner, V. D.; Parker, M. I., Feedback regulation of the alpha2(1) collagen gene via the Mek-Erk signaling pathway. IUBMB Life 2012, 64, (1), 87-98.

4. Dzobo, K.; Leaner, V. D.; Parker, M. I., Absence of feedback regulation in the synthesis of COL1A1. Life sciences 2014, 103, (1), 25-33.

5. Assoian, R. K.; Klein, E. A., Growth control by intracellular tension and extracellular stiffness. Trends in cell biology 2008, 18, (7), 347-352.

6. Vellon, L.; Menendez, J. A.; Lupu, R., $\alpha \vee \beta 3$ integrin regulates heregulin (HRG)-induced cell proliferation and survival in breast cancer. Oncogene 2005, 24, (23), 3759-3773.

7. Han, S.; Khuri, F. R.; Roman, J., Fibronectin stimulates non-small cell lung carcinoma cell growth through activation of Akt/mammalian target of rapamycin/S6 kinase and inactivation of LKB1/AMP-activated protein kinase signal pathways. Cancer research 2006, 66, (1), 315323.

8. Gopal, S.; Veracini, L.; Grall, D.; Butori, C.; Schaub, S.; Audebert, S.; Camoin, L.; Baudelet, E.; Radwanska, A.; Beghelli-de la Forest Divonne, S., Fibronectin-guided migration of carcinoma collectives. Nature communications 2017, 8, (1), 1-15.

9. $\quad$ Erdogan, B.; Ao, M.; White, L. M.; Means, A. L.; Brewer, B. M.; Yang, L.; Washington, M. K.; Shi, C.; Franco, O. E.; Weaver, A. M., Cancer-associated fibroblasts promote directional cancer cell migration by aligning fibronectin. Journal of Cell Biology 2017, 216, (11), 37993816.

10. Seguin, L.; Desgrosellier, J. S.; Weis, S. M.; Cheresh, D. A., Integrins and cancer: regulators of cancer stemness, metastasis, and drug resistance. Trends in cell biology 2015, 25, (4), 234240.

11. Hamidi, H.; Pietilä, M.; Ivaska, J., The complexity of integrins in cancer and new scopes for therapeutic targeting. British journal of cancer 2016, 115, (9), 1017-1023.

12. Attieh, Y.; Clark, A. G.; Grass, C.; Richon, S.; Pocard, M.; Mariani, P.; Elkhatib, N.; Betz, T.; Gurchenkov, B.; Vignjevic, D. M., Cancer-associated fibroblasts lead tumor invasion through integrin- $\beta 3$-dependent fibronectin assembly. Journal of Cell Biology 2017, 216, (11), 35093520.

13. Izumi, D.; Ishimoto, T.; Miyake, K.; Sugihara, H.; Eto, K.; Sawayama, H.; Yasuda, T.; Kiyozumi, Y.; Kaida, T.; Kurashige, J., CXCL12/CXCR4 activation by cancer-associated fibroblasts promotes integrin $\beta 1$ clustering and invasiveness in gastric cancer. International journal of cancer 2016, 138, (5), 1207-1219.

14. Zeltz, C.; Primac, I.; Erusappan, P.; Alam, J.; Noel, A.; Gullberg, D. In Cancer-associated fibroblasts in desmoplastic tumors: emerging role of integrins, Seminars in cancer biology, 2020; Elsevier: 2020; pp 166-181. 
15. Dzobo, K.; Dandara, C., Broadening Drug Design and Targets to Tumor Microenvironment? Cancer-Associated Fibroblast Marker Expression in Cancers and Relevance for Survival Outcomes. Omics : a journal of integrative biology 2020, 24, (6), 340-351.

16. Dzobo, K.; Dandara, C., Architecture of Cancer-Associated Fibroblasts in Tumor Microenvironment: Mapping Their Origins, Heterogeneity, and Role in Cancer Therapy Resistance. Omics : a journal of integrative biology 2020, 24, (6), 314-339.

17. Franco, O. E.; Shaw, A. K.; Strand, D. W.; Hayward, S. W. In Cancer associated fibroblasts in cancer pathogenesis, Seminars in cell \& developmental biology, 2010; Elsevier: 2010; pp 3339.

18. Bussard, K. M.; Mutkus, L.; Stumpf, K.; Gomez-Manzano, C.; Marini, F. C., Tumor-associated stromal cells as key contributors to the tumor microenvironment. Breast Cancer Research 2016, 18, (1), 1-11.

19. Castells, M.; Thibault, B.; Delord, J. P.; Couderc, B., Implication of tumor microenvironment in chemoresistance: tumor-associated stromal cells protect tumor cells from cell death. International journal of molecular sciences 2012, 13, (8), 9545-71.

20. Senthebane, D.; Jonker, T.; Rowe, A.; Thomford, N.; Munro, D.; Dandara, C.; Wonkam, A.; Govender, D.; Calder, B.; Soares, N., The role of tumor microenvironment in chemoresistance: 3D extracellular matrices as accomplices. International journal of molecular sciences 2018, 19, (10), 2861.

21. Senthebane, D. A.; Rowe, A.; Thomford, N. E.; Shipanga, H.; Munro, D.; Al Mazeedi, M. A.; Almazyadi, H. A.; Kallmeyer, K.; Dandara, C.; Pepper, M. S., The role of tumor microenvironment in chemoresistance: to survive, keep your enemies closer. International journal of molecular sciences 2017, 18, (7), 1586.

22. Bianconi, D.; Unseld, M.; Prager, G. W., Integrins in the Spotlight of Cancer. International journal of molecular sciences 2016, 17, (12).

23. Hynes, R. O., Integrins: bidirectional, allosteric signaling machines. Cell 2002, 110, (6), 67387.

24. Altei, W. F.; Pachane, B. C.; Dos Santos, P. K.; Ribeiro, L. N. M.; Sung, B. H.; Weaver, A. M.; Selistre-de-Araújo, H. S., Inhibition of $\alpha v \beta 3$ integrin impairs adhesion and uptake of tumorderived small extracellular vesicles. Cell communication and signaling : CCS 2020, 18, (1), 158.

25. Zhang, Y.; Xu, B.; Shi, J.; Li, J.; Lu, X.; Xu, L.; Yang, H.; Hamad, N.; Wang, C.; Napier, D.; He, S.; Liu, C.; Liu, Z.; Qian, H.; Chen, L.; Wei, X.; Zheng, X.; Huang, J. A.; Thibault, O.; Craven, R.; Wei, D.; Pan, Y.; Zhou, B. P.; Wu, Y.; Yang, X. H., BRD4 modulates vulnerability of triplenegative breast cancer to targeting of integrin-dependent signaling pathways. Cellular oncology (Dordrecht) 2020.

26. He, F.; Wang, Y.; Cai, W.; Li, M.; Dong, L., Reversal of EGFR inhibitors' resistance by codelivering EGFR and integrin $\alpha v \beta 3$ inhibitors with nanoparticles in non-small cell lung cancer. Bioscience reports 2019, 39, (8).

27. Zhang, L.; Gülses, A.; Purcz, N.; Weimer, J.; Wiltfang, J.; Açil, Y., A comparative assessment of the effects of integrin inhibitor cilengitide on primary culture of head and neck squamous cell carcinoma (HNSCC) and HNSCC cell lines. Clinical \& translational oncology : official publication of the Federation of Spanish Oncology Societies and of the National Cancer Institute of Mexico 2019, 21, (8), 1052-1060.

28. Zhu, X.; Tao, X.; Lu, W.; Ding, Y.; Tang, Y., Blockade of integrin $\beta 3$ signals to reverse the stemlike phenotype and drug resistance in melanoma. Cancer chemotherapy and pharmacology 2019, 83, (4), 615-624.

29. Hynes, R. O., The emergence of integrins: a personal and historical perspective. Matrix Biol 2004, 23, (6), 333-40. 
30. Hynes, R. O.; Lively, J. C.; McCarty, J. H.; Taverna, D.; Francis, S. E.; Hodivala-Dilke, K.; Xiao, Q., The diverse roles of integrins and their ligands in angiogenesis. Cold Spring Harb Symp Quant Biol 2002, 67, 143-53.

31. Juliano, R. L.; Varner, J. A., Adhesion molecules in cancer: the role of integrins. Curr Opin Cell Biol 1993, 5, (5), 812-8.

32. De Franceschi, N.; Hamidi, H.; Alanko, J.; Sahgal, P.; Ivaska, J., Integrin traffic-the update. Journal of cell science 2015, 128, (5), 839-852.

33. Pytela, R.; Pierschbacher, M. D.; Ruoslahti, E., Identification and isolation of a $140 \mathrm{kd}$ cell surface glycoprotein with properties expected of a fibronectin receptor. Cell 1985, 40, (1), 191-198.

34. Aota, S. I.; Yamada, K. M., Fibronectin and cell adhesion: specificity of integrin-ligand interaction. Advances in enzymology and related areas of molecular biology 1995, 70, 1-22.

35. Desgrosellier, J. S.; Cheresh, D. A., Integrins in cancer: biological implications and therapeutic opportunities. Nature Reviews Cancer 2010, 10, (1), 9-22.

36. Critchley, D. R., Focal adhesions-the cytoskeletal connection. Current opinion in cell biology 2000, 12, (1), 133-139.

37. Burridge, K.; Chrzanowska-Wodnicka, M., Focal adhesions, contractility, and signaling. Annual review of cell and developmental biology 1996, 12, (1), 463-519.

38. Berrier, A. L.; Yamada, K. M., Cell-matrix adhesion. Journal of cellular physiology 2007, 213, (3), 565-573.

39. Lock, J. G.; Wehrle-Haller, B.; Strömblad, S. In Cell-matrix adhesion complexes: master control machinery of cell migration, Seminars in cancer biology, 2008; Elsevier: 2008; pp 6576.

40. Arias-Salgado, E. G.; Lizano, S.; Sarkar, S.; Brugge, J. S.; Ginsberg, M. H.; Shattil, S. J., Src kinase activation by direct interaction with the integrin $\beta$ cytoplasmic domain. Proceedings of the National Academy of Sciences 2003, 100, (23), 13298-13302.

41. Miyamoto, S.; Teramoto, H.; Gutkind, J. S.; Yamada, K. M., Integrins can collaborate with growth factors for phosphorylation of receptor tyrosine kinases and MAP kinase activation: roles of integrin aggregation and occupancy of receptors. Journal of Cell Biology 1996, 135, (6), 1633-1642.

42. Xue, Z.-H.; Zhao, C.-Q.; Chua, G.-L.; Tan, S.-W.; Tang, X.-Y.; Wong, S.-C.; Tan, S.-M., Integrin $\alpha \mathrm{M} \beta 2$ clustering triggers phosphorylation and activation of protein kinase $C \delta$ that regulates transcription factor Foxp1 expression in monocytes. The Journal of Immunology 2010, 184, (7), 3697-3709.

43. Calderwood, D. A.; Shattil, S. J.; Ginsberg, M. H., Integrins and actin filaments: reciprocal regulation of cell adhesion and signaling. Journal of Biological Chemistry 2000, 275, (30), 22607-22610.

44. Schwartz, M. A., Integrins and extracellular matrix in mechanotransduction. Cold Spring Harbor perspectives in biology 2010, 2, (12), a005066.

45. Legate, K. R.; Montañez, E.; Kudlacek, O.; Füssler, R., ILK, PINCH and parvin: the tIPP of integrin signalling. Nature reviews Molecular cell biology 2006, 7, (1), 20-31.

46. Sakai, T.; Li, S.; Docheva, D.; Grashoff, C.; Sakai, K.; Kostka, G.; Braun, A.; Pfeifer, A.; Yurchenco, P. D.; Fässler, R., Integrin-linked kinase (ILK) is required for polarizing the epiblast, cell adhesion, and controlling actin accumulation. Genes \& development 2003, 17, (7), 926-940.

47. Zöller, M., Tetraspanins: push and pull in suppressing and promoting metastasis. Nature Reviews Cancer 2009, 9, (1), 40-55.

48. Hemler, M. E., Tetraspanin functions and associated microdomains. Nature reviews Molecular cell biology 2005, 6, (10), 801-811.

49. Han, J.; Lim, C. J.; Watanabe, N.; Soriani, A.; Ratnikov, B.; Calderwood, D. A.; PuzonMcLaughlin, W.; Lafuente, E. M.; Boussiotis, V. A.; Shattil, S. J., Reconstructing and 
deconstructing agonist-induced activation of integrin $\alpha$ llb $\beta 3$. Current Biology 2006, 16, (18), 1796-1806.

50. Lee, H.-S.; Lim, C. J.; Puzon-McLaughlin, W.; Shattil, S. J.; Ginsberg, M. H., RIAM activates integrins by linking talin to ras GTPase membrane-targeting sequences. Journal of Biological Chemistry 2009, 284, (8), 5119-5127.

51. Dzobo, K.; Motaung, K.; Adesida, A., Recent Trends in Decellularized Extracellular Matrix Bioinks for 3D Printing: An Updated Review. International journal of molecular sciences 2019, 20, (18).

52. Petitclerc, E.; Strömblad, S.; von Schalscha, T. L.; Mitjans, F.; Piulats, J.; Montgomery, A. M.; Cheresh, D. A.; Brooks, P. C., Integrin av $\beta 3$ promotes M21 melanoma growth in human skin by regulating tumor cell survival. Cancer research 1999, 59, (11), 2724-2730.

53. Lamb, L. E.; Zarif, J. C.; Miranti, C. K., The androgen receptor induces integrin $\alpha 6 \beta 1$ to promote prostate tumor cell survival via NF-KB and Bcl-xL Independently of PI3K signaling. Cancer research 2011, 71, (7), 2739-2749.

54. Aoudjit, F.; Vuori, K., Integrin signaling in cancer cell survival and chemoresistance. Chemotherapy research and practice 2012, 2012.

55. Ahmed, N.; Riley, C.; Rice, G. E.; Quinn, M. A.; Baker, M. S., $\alpha v \beta 6$ integrin-A marker for the malignant potential of epithelial ovarian cancer. Journal of Histochemistry \& Cytochemistry 2002, 50, (10), 1371-1379.

56. Ahmed, N.; Pansino, F.; Clyde, R.; Murthi, P.; Quinn, M.; Rice, G.; Agrez, M.; Mok, S.; Baker, M., Overexpression of $\alpha v \beta 6$ integrin in serous epithelial ovarian cancer regulates extracellular matrix degradation via the plasminogen activation cascade. Carcinogenesis 2002, 23, (2), 237-244.

57. Agrez, M.; Gu, X.; Turton, J.; Meldrum, C.; Niu, J.; Antalis, T.; Howard, E. W., The av $\beta 6$ integrin induces gelatinase $B$ secretion in colon cancer cells. International journal of cancer 1999, 81, (1), 90-97.

58. Thomas, G. J.; Lewis, M. P.; Whawell, S. A.; Russell, A.; Sheppard, D.; Hart, I. R.; Speight, P. M.; Marshall, J. F., Expression of the $\alpha v \beta 6$ integrin promotes migration and invasion in squamous carcinoma cells. Journal of Investigative Dermatology 2001, 117, (1), 67-73.

59. Slack-Davis, J. K.; Atkins, K. A.; Harrer, C.; Hershey, E. D.; Conaway, M., Vascular cell adhesion molecule-1 is a regulator of ovarian cancer peritoneal metastasis. Cancer research 2009, 69, (4), 1469-1476.

60. Landen, C. N.; Kim, T.-J.; Lin, Y. G.; Merritt, W. M.; Kamat, A. A.; Han, L. Y.; Spannuth, W. A.; Nick, A. M.; Jennnings, N. B.; Kinch, M. S., Tumor-selective response to antibody-mediated targeting of $\alpha \mathrm{v} \beta 3$ integrin in ovarian cancer. Neoplasia (New York, NY) 2008, 10, (11), 1259.

61. Zutter, M. M.; Santoro, S. A.; Staatz, W. D.; Tsung, Y. L., Re-expression of the alpha 2 beta 1 integrin abrogates the malignant phenotype of breast carcinoma cells. Proceedings of the National Academy of Sciences 1995, 92, (16), 7411-7415.

62. Zutter, M. M.; Krigman, H. R.; Santoro, S., Altered integrin expression in adenocarcinoma of the breast. Analysis by in situ hybridization. The American journal of pathology 1993, 142, (5), 1439.

63. Zutter, M. M.; Mazoujian, G.; Santoro, S., Decreased expression of integrin adhesive protein receptors in adenocarcinoma of the breast. The American journal of pathology 1990, 137, (4), 863.

64. Kaur, S.; Kenny, H. A.; Jagadeeswaran, S.; Zillhardt, M. R.; Montag, A. G.; Kistner, E.; Yamada, S. D.; Mitra, A. K.; Lengyel, E., $\beta 3$-integrin expression on tumor cells inhibits tumor progression, reduces metastasis, and is associated with a favorable prognosis in patients with ovarian cancer. The American journal of pathology 2009, 175, (5), 2184-2196.

65. Thomas, G.; Jones, J.; Speight, P., Integrins and oral cancer. Oral oncology 1997, 33, (6), 381388. 
66. Meyer, A.; van Golen, C. M.; Kim, B.; van Golen, K. L.; Feldman, E. L., Integrin expression regulates neuroblastoma attachment and migration. Neoplasia 2004, 6, (4), 332-342.

67. McCabe, N. P.; De, S.; Vasanji, A.; Brainard, J.; Byzova, T. V., Prostate cancer specific integrin $\alpha v \beta 3$ modulates bone metastatic growth and tissue remodeling. Oncogene 2007, 26, (42), 6238-6243.

68. Gruber, G.; Hess, J.; Stiefel, C.; Aebersold, D.; Zimmer, Y.; Greiner, R.; Studer, U.; Altermatt, H.; Hlushchuk, R.; Djonov, V., Correlation between the tumoral expression of $\beta$ 3-integrin and outcome in cervical cancer patients who had undergone radiotherapy. British journal of cancer 2005, 92, (1), 41-46.

69. Hazelbag, S.; Kenter, G. G.; Gorter, A.; Dreef, E. J.; Koopman, L. A.; Violette, S. M.; Weinreb, P. H.; Fleuren, G. J., Overexpression of the $\alpha v \beta 6$ integrin in cervical squamous cell carcinoma is a prognostic factor for decreased survival. The Journal of Pathology: A Journal of the Pathological Society of Great Britain and Ireland 2007, 212, (3), 316-324.

70. Hieken, T. J.; Ronan, S. G.; Farolan, M.; Shilkaitis, A. L.; Das Gupta, T. K., Molecular prognostic markers in intermediate-thickness cutaneous malignant melanoma. Cancer: Interdisciplinary International Journal of the American Cancer Society 1999, 85, (2), 375-382.

71. Nip, J.; Shibata, H.; Loskutoff, D. J.; Cheresh, D. A.; Brodt, P., Human melanoma cells derived from lymphatic metastases use integrin alpha $v$ beta 3 to adhere to lymph node vitronectin. The Journal of clinical investigation 1992, 90, (4), 1406-1413.

72. Adachi, M.; Taki, T.; Higashiyama, M.; Kohno, N.; Inufusa, H.; Miyake, M., Significance of integrin $\alpha 5$ gene expression as a prognostic factor in node-negative non-small cell lung cancer. Clinical cancer research 2000, 6, (1), 96-101.

73. Hosotani, R.; Kawaguchi, M.; Masui, T.; Koshiba, T.; Ida, J.; Fujimoto, K.; Wada, M.; Doi, R.; Imamura, M., Expression of integrin av $\beta 3$ in pancreatic carcinoma: relation to MMP-2 activation and lymph node metastasis. Pancreas 2002, 25, (2), e30-e35.

74. Das, A.; Monteiro, M.; Barai, A.; Kumar, S.; Sen, S., MMP proteolytic activity regulates cancer invasiveness by modulating integrins. Scientific reports 2017, 7, (1), 14219.

75. Kren, A.; Baeriswyl, V.; Lehembre, F.; Wunderlin, C.; Strittmatter, K.; Antoniadis, H.; Fässler, R.; Cavallaro, U.; Christofori, G., Increased tumor cell dissemination and cellular senescence in the absence of $\beta 1$-integrin function. The EMBO Journal 2007, 26, (12), 2832-2842.

76. Aoudjit, F.; Vuori, K., Integrin signaling inhibits paclitaxel-induced apoptosis in breast cancer cells. Oncogene 2001, 20, (36), 4995-5004.

77. Scatena, M.; Almeida, M.; Chaisson, M. L.; Fausto, N.; Nicosia, R. F.; Giachelli, C. M., NF-kB mediates $\alpha v \beta 3$ integrin-induced endothelial cell survival. The Journal of cell biology 1998, 141, (4), 1083-1093.

78. Courter, D. L.; Lomas, L.; Scatena, M.; Giachelli, C. M., Src kinase activity is required for integrin $\alpha \mathrm{V} \beta 3$-mediated activation of nuclear factor-кB. Journal of Biological Chemistry 2005, 280, (13), 12145-12151.

79. Matter, M. L.; Ruoslahti, E., A Signaling Pathway from the $\alpha 5 \beta 1$ and $\alpha v \beta 3$ Integrins That Elevatesbcl-2 Transcription. Journal of Biological Chemistry 2001, 276, (30), 27757-27763.

80. Uhm, J. H.; Dooley, N. P.; Kyritsis, A. P.; Rao, J. S.; Gladson, C. L., Vitronectin, a gliomaderived extracellular matrix protein, protects tumor cells from apoptotic death. Clinical Cancer Research 1999, 5, (6), 1587-1594.

81. Hood, J. D.; Frausto, R.; Kiosses, W. B.; Schwartz, M. A.; Cheresh, D. A., Differential $\alpha v$ integrin-mediated Ras-ERK signaling during two pathways of angiogenesis. The Journal of cell biology 2003, 162, (5), 933-943.

82. Alavi, A.; Hood, J. D.; Frausto, R.; Stupack, D. G.; Cheresh, D. A., Role of Raf in vascular protection from distinct apoptotic stimuli. Science 2003, 301, (5629), 94-96.

83. Reynolds, L. E.; Wyder, L.; Lively, J. C.; Taverna, D.; Robinson, S. D.; Huang, X.; Sheppard, D.; Hynes, R. O.; Hodivala-Dilke, K. M., Enhanced pathological angiogenesis in mice lacking $\beta 3$ integrin or $\beta 3$ and $\beta 5$ integrins. Nature medicine 2002, 8, (1), 27-34. 
84. Reynolds, A. R.; Reynolds, L. E.; Nagel, T. E.; Lively, J. C.; Robinson, S. D.; Hicklin, D. J.; Bodary, S. C.; Hodivala-Dilke, K. M., Elevated Flk1 (vascular endothelial growth factor receptor 2) signaling mediates enhanced angiogenesis in $\beta 3$-integrin-deficient mice. Cancer Research 2004, 64, (23), 8643-8650.

85. Weis, S. M.; Lindquist, J. N.; Barnes, L. A.; Lutu-Fuga, K. M.; Cui, J.; Wood, M. R.; Cheresh, D. A., Cooperation between VEGF and $\beta 3$ integrin during cardiac vascular development. Blood 2007, 109, (5), 1962-1970.

86. Varner, J. A.; Emerson, D. A.; Juliano, R. L., Integrin alpha 5 beta 1 expression negatively regulates cell growth: reversal by attachment to fibronectin. Molecular biology of the cell $1995,6,(6), 725-740$.

87. Kanamori, M.; Berg, S. R. V.; Bergers, G.; Berger, M. S.; Pieper, R. O., Integrin $\beta 3$ overexpression suppresses tumor growth in a human model of gliomagenesis: implications for the role of $\beta 3$ overexpression in glioblastoma multiforme. Cancer research 2004, 64, (8), 2751-2758.

88. Danen, E. H.; van Kraats, A. A.; Cornelissen, I. M.; Ruiter, D. J.; van Muijen, G. N., Integrin $\beta 3$ cDNA transfection into a highly metastatic av $\beta 3$-negative human melanoma cell line inhibits invasion and experimental metastasis. Biochemical and biophysical research communications 1996, 226, (1), 75-81.

89. Dzobo, K., Taking a Full Snapshot of Cancer Biology: Deciphering the Tumor Microenvironment for Effective Cancer Therapy in the Oncology Clinic. Omics : a journal of integrative biology 2020.

90. Dzobo, K.; Senthebane, D.; Ganz, C.; Thomford, N., The Significance of Cancer Stem Cell Markers' Gene Expression and Relevance for Survival Outcomes. In Preprints.org: 2020.

91. Dzobo, K.; Senthebane, D. A.; Ganz, C.; Thomford, N. E.; Wonkam, A.; Dandara, C., Advances in Therapeutic Targeting of Cancer Stem Cells within the Tumor Microenvironment: An Updated Review. Cells 2020, 9, (8).

92. Dzobo, K.; Senthebane, D. A.; Rowe, A.; Thomford, N. E.; Mwapagha, L. M.; Al-Awwad, N.; Dandara, C.; Parker, M. I., Cancer Stem Cell Hypothesis for Therapeutic Innovation in Clinical Oncology? Taking the Root Out, Not Chopping the Leaf. Omics : a journal of integrative biology 2016, 20, (12), 681-691.

93. Nieberler, M.; Reuning, U.; Reichart, F.; Notni, J.; Wester, H.-J.; Schwaiger, M.; Weinmüller, M.; Räder, A.; Steiger, K.; Kessler, H., Exploring the role of RGD-recognizing integrins in cancer. Cancers 2017, 9, (9), 116.

94. Asselin-Labat, M.-L.; Sutherland, K. D.; Barker, H.; Thomas, R.; Shackleton, M.; Forrest, N. C.; Hartley, L.; Robb, L.; Grosveld, F. G.; van der Wees, J., Gata-3 is an essential regulator of mammary-gland morphogenesis and luminal-cell differentiation. Nature cell biology 2007, 9, (2), 201-209.

95. Vaillant, F.; Asselin-Labat, M.-L.; Shackleton, M.; Forrest, N. C.; Lindeman, G. J.; Visvader, J. E., The mammary progenitor marker CD61/ $\beta 3$ integrin identifies cancer stem cells in mouse models of mammary tumorigenesis. Cancer research 2008, 68, (19), 7711-7717.

96. Luo, M.; Fan, H.; Nagy, T.; Wei, H.; Wang, C.; Liu, S.; Wicha, M. S.; Guan, J.-L., Mammary epithelial-specific ablation of the focal adhesion kinase suppresses mammary tumorigenesis by affecting mammary cancer stem/progenitor cells. Cancer research 2009, 69, (2), 466-474.

97. Samanna, V.; Wei, H.; Ego-Osuala, D.; Chellaiah, M. A., Alpha-V-dependent outside-in signaling is required for the regulation of CD44 surface expression, MMP-2 secretion, and cell migration by osteopontin in human melanoma cells. Experimental Cell Research 2006, 312, (12), 2214-2230.

98. Avraamides, C. J.; Garmy-Susini, B.; Varner, J. A., Integrins in angiogenesis and lymphangiogenesis. Nature Reviews Cancer 2008, 8, (8), 604-617.

99. McDonald, D. M.; Baluk, P., Significance of blood vessel leakiness in cancer. In AACR: 2002. 
100. Brown, L. F.; Dvorak, A. M.; Dvorak, H. F., Leaky vessels, fibrin deposition, and fibrosis: a sequence of events common to solid tumors and to many other types of disease. Am Rev Respir Dis 1989, 140, (4), 1104-1107.

101. Brooks, P. C.; Clark, R. A.; Cheresh, D. A., Requirement of vascular integrin alpha v beta 3 for angiogenesis. Science 1994, 264, (5158), 569-571.

102. Stupack, D. G.; Cheresh, D. A., ECM remodeling regulates angiogenesis: endothelial integrins look for new ligands. Science's STKE 2002, 2002, (119), pe7-pe7.

103. Eliceiri, B. P.; Cheresh, D. A., The role of $\alpha v$ integrins during angiogenesis: insights into potential mechanisms of action and clinical development. The Journal of clinical investigation 1999, 103, (9), 1227-1230.

104. Davis, G. E., Affinity of integrins for damaged extracellular matrix: $\alpha \vee \beta 3$ binds to denatured collagen type I through RGD sites. Biochemical and biophysical research communications 1992, 182, (3), 1025-1031.

105. Friedlander, M.; Brooks, P. C.; Shaffer, R. W.; Kincaid, C. M.; Varner, J. A.; Cheresh, D. A., Definition of two angiogenic pathways by distinct $\alpha v$ integrins. Science 1995, 270, (5241), 1500-1502.

106. Brooks, P. C.; Montgomery, A. M.; Rosenfeld, M.; Reisfeld, R. A.; Hu, T.; Klier, G.; Cheresh, D. A., Integrin $\alpha v \beta 3$ antagonists promote tumor regression by inducing apoptosis of angiogenic blood vessels. Cell 1994, 79, (7), 1157-1164.

107. Goede, V.; Schmidt, T.; Kimmina, S.; Kozian, D.; Augustin, H. G., Analysis of blood vessel maturation processes during cyclic ovarian angiogenesis. Laboratory investigation 1998, 78, (11), 1385-1394.

108. Raza, A.; Franklin, M. J.; Dudek, A. Z., Pericytes and vessel maturation during tumor angiogenesis and metastasis. American journal of hematology 2010, 85, (8), 593-598.

109. Korff, T.; Kimmina, S.; MARTINY-BARON, G.; Augustin, H. G., Blood vessel maturation in a 3-dimensional spheroidal coculture model: direct contact with smooth muscle cells regulates endothelial cell quiescence and abrogates VEGF responsiveness. The FASEB journal 2001, 15, (2), 447-457.

110. Klein, D.; Weißhardt, P.; Kleff, V.; Jastrow, H.; Jakob, H. G.; Ergün, S., Vascular wall-resident CD44+ multipotent stem cells give rise to pericytes and smooth muscle cells and contribute to new vessel maturation. PloS one 2011, 6, (5), e20540.

111. Garmy-Susini, B.; Jin, H.; Zhu, Y.; Sung, R.-J.; Hwang, R.; Varner, J., Integrin $\alpha 4 \beta$ 1-VCAM-1mediated adhesion between endothelial and mural cells is required for blood vessel maturation. The Journal of clinical investigation 2005, 115, (6), 1542-1551.

112. Fukumura, D.; Jain, R. K., Tumor microvasculature and microenvironment: Targets for antiangiogenesis and normalization. Microvascular Research 2007, 74, (2), 72-84.

113. Fukumura, D.; Jain, R. K., Tumor microenvironment abnormalities: causes, consequences, and strategies to normalize. Journal of cellular biochemistry 2007, 101, (4), 937-949.

114. Jain, R. K.; Tong, R. T.; Munn, L. L., Effect of vascular normalization by antiangiogenic therapy on interstitial hypertension, peritumor edema, and lymphatic metastasis: insights from a mathematical model. Cancer research 2007, 67, (6), 2729-2735.

115. Tong, R. T.; Boucher, Y.; Kozin, S. V.; Winkler, F.; Hicklin, D. J.; Jain, R. K., Vascular normalization by vascular endothelial growth factor receptor 2 blockade induces a pressure gradient across the vasculature and improves drug penetration in tumors. Cancer research 2004, 64, (11), 3731-3736.

116. Conti, J. A.; Kendall, T. J.; Bateman, A.; Armstrong, T. A.; Papa-Adams, A.; Xu, Q.; Packham, G.; Primrose, J. N.; Benyon, R. C.; Iredale, J. P., The desmoplastic reaction surrounding hepatic colorectal adenocarcinoma metastases aids tumor growth and survival via $\alpha v$ integrin ligation. Clinical Cancer Research 2008, 14, (20), 6405-6413.

117. Zhu, C.-Q.; Popova, S. N.; Brown, E. R.; Barsyte-Lovejoy, D.; Navab, R.; Shih, W.; Li, M.; Lu, M.; Jurisica, I.; Penn, L. Z., Integrin a11 regulates IGF2 expression in fibroblasts to enhance 
tumorigenicity of human non-small-cell lung cancer cells. Proceedings of the National Academy of Sciences 2007, 104, (28), 11754-11759.

118. Ghossein, R. A.; Bhattacharya, S.; Rosai, J., Molecular detection of micrometastases and circulating tumor cells in solid tumors. Clinical Cancer Research 1999, 5, (8), 1950-1960.

119. Adams, D. L.; Martin, S. S.; Alpaugh, R. K.; Charpentier, M.; Tsai, S.; Bergan, R. C.; Ogden, I. M.; Catalona, W.; Chumsri, S.; Tang, C.-M., Circulating giant macrophages as a potential biomarker of solid tumors. Proceedings of the National Academy of Sciences 2014, 111, (9), 3514-3519.

120. Taverna, D.; Moher, H.; Crowley, D.; Borsig, L.; Varki, A.; Hynes, R. O., Increased primary tumor growth in mice null for $\beta 3$-or $\beta 3 / \beta 5$-integrins or selectins. Proceedings of the National Academy of Sciences 2004, 101, (3), 763-768.

121. Feng, W.; McCabe, N. P.; Mahabeleshwar, G. H.; Somanath, P. R.; Phillips, D. R.; Byzova, T. V., The angiogenic response is dictated by $\beta 3$ integrin on bone marrow-derived cells. The Journal of cell biology 2008, 183, (6), 1145-1157.

122. Jin, H.; Aiyer, A.; Su, J.; Borgstrom, P.; Stupack, D.; Friedlander, M.; Varner, J., A homing mechanism for bone marrow-derived progenitor cell recruitment to the neovasculature. The Journal of clinical investigation 2006, 116, (3), 652-662.

123. Jin, H.; Su, J.; Garmy-Susini, B.; Kleeman, J.; Varner, J., Integrin $\alpha 4 \beta 1$ promotes monocyte trafficking and angiogenesis in tumors. Cancer research 2006, 66, (4), 2146-2152.

124. Mammadova-Bach, E.; Zigrino, P.; Brucker, C.; Bourdon, C.; Freund, M.; De Arcangelis, A.; Abrams, S. I.; Orend, G.; Gachet, C.; Mangin, P. H., Platelet integrin $\alpha 6 \beta 1$ controls lung metastasis through direct binding to cancer cell-derived ADAM9. JCl insight 2016, 1, (14).

125. Gay, L. J.; Felding-Habermann, B., Platelets alter tumor cell attributes to propel metastasis: programming in transit. Cancer cell 2011, 20, (5), 553-554.

126. Bakewell, S. J.; Nestor, P.; Prasad, S.; Tomasson, M. H.; Dowland, N.; Mehrotra, M.; Scarborough, R.; Kanter, J.; Abe, K.; Phillips, D., Platelet and osteoclast $\beta 3$ integrins are critical for bone metastasis. Proceedings of the National Academy of Sciences 2003, 100, (24), 14205-14210.

127. Felding-Habermann, B.; Habermann, R.; Saldívar, E.; Ruggeri, Z. M., Role of 3 integrins in melanoma cell adhesion to activated platelets under flow. Journal of Biological Chemistry 1996, 271, (10), 5892-5900.

128. Jain, S.; Zuka, M.; Liu, J.; Russell, S.; Dent, J.; Guerrero, J. A.; Forsyth, J.; Maruszak, B.; Gartner, T. K.; Felding-Habermann, B., Platelet glycoprotein Ibo supports experimental lung metastasis. Proceedings of the National Academy of Sciences 2007, 104, (21), 9024-9028.

129. Trikha, M.; Zhou, Z.; Timar, J.; Raso, E.; Kennel, M.; Emmell, E.; Nakada, M. T., Multiple roles for platelet GPIIb/IIla and $\alpha v \beta 3$ integrins in tumor growth, angiogenesis, and metastasis. Cancer research 2002, 62, (10), 2824-2833.

130. Guo, W.; Pylayeva, Y.; Pepe, A.; Yoshioka, T.; Muller, W. J.; Inghirami, G.; Giancotti, F. G., $\beta 4$ integrin amplifies ErbB2 signaling to promote mammary tumorigenesis. Cell 2006, 126, (3), 489-502.

131. White, D. E.; Kurpios, N. A.; Zuo, D.; Hassell, J. A.; Blaess, S.; Mueller, U.; Muller, W. J., Targeted disruption of $\beta 1$-integrin in a transgenic mouse model of human breast cancer reveals an essential role in mammary tumor induction. Cancer cell 2004, 6, (2), 159-170.

132. Macias-Perez, I.; Borza, C.; Chen, X.; Yan, X.; Ibanez, R.; Mernaugh, G.; Matrisian, L. M.; Zent, R.; Pozzi, A., Loss of integrin $\alpha 1 \beta 1$ ameliorates Kras-induced lung cancer. Cancer research 2008, 68, (15), 6127-6135.

133. Huveneers, S.; van den Bout, I.; Sonneveld, P.; Sancho, A.; Sonnenberg, A.; Danen, E. H., Integrin $\alpha v \beta 3$ controls activity and oncogenic potential of primed c-Src. Cancer research 2007, 67, (6), 2693-2700. 
134. Shimizu, H.; Seiki, T.; Asada, M.; Yoshimatsu, K.; Koyama, N., $\alpha 6 \beta 1$ integrin induces proteasome-mediated cleavage of erbB2 in breast cancer cells. Oncogene 2003, 22, (6), 831839.

135. Assoian, R. K.; Schwartz, M. A., Coordinate signaling by integrins and receptor tyrosine kinases in the regulation of $\mathrm{G} 1$ phase cell-cycle progression. Current opinion in genetics \& development 2001, 11, (1), 48-53.

136. Tai, Y.-T.; Podar, K.; Catley, L.; Tseng, Y.-H.; Akiyama, M.; Shringarpure, R.; Burger, R.; Hideshima, T.; Chauhan, D.; Mitsiades, N., Insulin-like growth factor-1 induces adhesion and migration in human multiple myeloma cells via activation of $\beta 1$-integrin and phosphatidylinositol 3'-kinase/AKT signaling. Cancer research 2003, 63, (18), 5850-5858.

137. Ning, Y.; Buranda, T.; Hudson, L. G., Activated epidermal growth factor receptor induces integrin $\alpha 2$ internalization via caveolae/raft-dependent endocytic pathway. Journal of Biological Chemistry 2007, 282, (9), 6380-6387.

138. Ning, Y.; Zeineldin, R.; Liu, Y.; Rosenberg, M.; Stack, M. S.; Hudson, L. G., Down-regulation of integrin $\alpha 2$ surface expression by mutant epidermal growth factor receptor (EGFRvIII) induces aberrant cell spreading and focal adhesion formation. Cancer research 2005, 65, (20), 9280-9286.

139. Ignotz, R. A.; Massagué, J., Cell adhesion protein receptors as targets for transforming growth factor- $\beta$ action. Cell 1987, 51, (2), 189-197.

140. Wang, D.; Sun, L.; Zborowska, E.; Willson, J. K.; Gong, J.; Verraraghavan, J.; Brattain, M. G., Control of type II transforming growth factor- $\beta$ receptor expression by integrin ligation. Journal of Biological Chemistry 1999, 274, (18), 12840-12847.

141. De, S.; Razorenova, O.; McCabe, N. P.; O'Toole, T.; Qin, J.; Byzova, T. V., VEGF-integrin interplay controls tumor growth and vascularization. Proceedings of the National Academy of Sciences 2005, 102, (21), 7589-7594.

142. Wang, S. E.; Xiang, B.; Zent, R.; Quaranta, V.; Pozzi, A.; Arteaga, C. L., Transforming growth factor $\beta$ induces clustering of HER2 and integrins by activating Src-focal adhesion kinase and receptor association to the cytoskeleton. Cancer research 2009, 69, (2), 475-482.

143. Joensuu, H.; Isola, J.; Lundin, M.; Salminen, T.; Holli, K.; Kataja, V.; Pylkkänen, L.; Turpeenniemi-Hujanen, T.; von Smitten, K.; Lundin, J., Amplification of erbB2 and erbB2 expression are superior to estrogen receptor status as risk factors for distant recurrence in pT1NOMO breast cancer: a nationwide population-based study. Clinical cancer research 2003, 9, (3), 923-930.

144. Tsutsui, S.; Ohno, S.; Murakami, S.; Hachitanda, Y.; Oda, S., Prognostic value of c-erbB2 expression in breast cancer. Journal of surgical oncology 2002, 79, (4), 216-223.

145. Shen, Z. Y.; Zhang, Z. Z.; Liu, H.; Zhao, E. H.; Cao, H., miR-375 inhibits the proliferation of gastric cancer cells by repressing ERBB2 expression. Experimental and therapeutic medicine 2014, 7, (6), 1757-1761.

146. Roychowdhury, D. F.; Tseng Jr, A.; Fu, K. K.; Weinberg, V.; Weidner, N., New prognostic factors in nasopharyngeal carcinoma: Tumor angiogenesis and C-erbB2 expression. Cancer: Interdisciplinary International Journal of the American Cancer Society 1996, 77, (8), 14191426.

147. Brooks, P. C.; Klemke, R. L.; Schon, S.; Lewis, J. M.; Schwartz, M. A.; Cheresh, D. A., Insulinlike growth factor receptor cooperates with integrin alpha $v$ beta 5 to promote tumor cell dissemination in vivo. The Journal of clinical investigation 1997, 99, (6), 1390-1398.

148. Klemke, R. L.; Yebra, M.; Bayna, E. M.; Cheresh, D. A., Receptor tyrosine kinase signaling required for integrin alpha $v$ beta 5 -directed cell motility but not adhesion on vitronectin. The Journal of Cell Biology 1994, 127, (3), 859-866.

149. Ricono, J. M.; Huang, M.; Barnes, L. A.; Lau, S. K.; Weis, S. M.; Schlaepfer, D. D.; Hanks, S. K.; Cheresh, D. A., Specific cross-talk between epidermal growth factor receptor and integrin 
av $\beta 5$ promotes carcinoma cell invasion and metastasis. Cancer research 2009, 69, (4), 13831391.

150. Pouliot, N.; Nice, E. C.; Burgess, A. W., Laminin-10 mediates basal and EGF-stimulated motility of human colon carcinoma cells via $\alpha 3 \beta 1$ and $\alpha 6 \beta 4$ integrins. Experimental cell research 2001, 266, (1), 1-10.

151. Yang, C.; Zeisberg, M.; Lively, J. C.; Nyberg, P.; Afdhal, N.; Kalluri, R., Integrin $\alpha 1 \beta 1$ and $\alpha 2 \beta 1$ are the key regulators of hepatocarcinoma cell invasion across the fibrotic matrix microenvironment. Cancer research 2003, 63, (23), 8312-8317.

152. Bertotti, A.; Comoglio, P. M.; Trusolino, L., $\beta 4$ integrin is a transforming molecule that unleashes Met tyrosine kinase tumorigenesis. Cancer research 2005, 65, (23), 10674-10679.

153. Bertotti, A.; Comoglio, P. M.; Trusolino, L., $\beta 4$ integrin activates a Shp2-Src signaling pathway that sustains HGF-induced anchorage-independent growth. The Journal of cell biology 2006, 175, (6), 993-1003.

154. Crouch, S.; Spidel, C. S.; Lindsey, J. S., HGF and ligation of $\alpha v \beta 5$ integrin induce a novel, cancer cell-specific gene expression required for cell scattering. Experimental cell research 2004, 292, (2), 274-287.

155. Oft, M.; Peli, J.; Rudaz, C.; Schwarz, H.; Beug, H.; Reichmann, E., TGF-beta1 and Ha-Ras collaborate in modulating the phenotypic plasticity and invasiveness of epithelial tumor cells. Genes \& development 1996, 10, (19), 2462-2477.

156. Welch, D. R.; Fabra, A.; Nakajima, M., Transforming growth factor beta stimulates mammary adenocarcinoma cell invasion and metastatic potential. Proceedings of the National Academy of Sciences 1990, 87, (19), 7678-7682.

157. Vo, B. T.; Morton Jr, D.; Komaragiri, S.; Millena, A. C.; Leath, C.; Khan, S. A., TGF-ß effects on prostate cancer cell migration and invasion are mediated by PGE2 through activation of $\mathrm{PI3K} / \mathrm{AKT} / \mathrm{mTOR}$ pathway. Endocrinology 2013, 154, (5), 1768-1779.

158. Ludbrook, S. B.; Barry, S. T.; Delves, C. J.; Horgan, C. M., The integrin alphavbeta3 is a receptor for the latency-associated peptides of transforming growth factors beta1 and beta3. Biochemical Journal 2003, 369, (2), 311-318.

159. Lu, M.; Munger, J. S.; Steadele, M.; Busald, C.; Tellier, M.; Schnapp, L. M., Integrin $\alpha 8 \beta 1$ mediates adhesion to LAP-TGFß1. Journal of Cell Science 2002, 115, (23), 4641-4648.

160. Munger, J. S.; Harpel, J. G.; Giancotti, F. G.; Rifkin, D. B., Interactions between growth factors and integrins: latent forms of transforming growth factor- $\beta$ are ligands for the integrin $\alpha v \beta 1$. Molecular biology of the cell 1998, 9, (9), 2627-2638.

161. Annes, J. P.; Rifkin, D. B.; Munger, J. S., The integrin $\alpha \mathrm{V} \beta 6$ binds and activates latent TGF $\beta 3$. FEBS letters 2002, 511, (1-3), 65-68.

162. Marsh, D.; Dickinson, S.; Neill, G. W.; Marshall, J. F.; Hart, I. R.; Thomas, G. J., avß6 integrin promotes the invasion of morphoeic basal cell carcinoma through stromal modulation. Cancer research 2008, 68, (9), 3295-3303.

163. Van Aarsen, L. A. K.; Leone, D. R.; Ho, S.; Dolinski, B. M.; McCoon, P. E.; LePage, D. J.; Kelly, R.; Heaney, G.; Rayhorn, P.; Reid, C., Antibody-mediated blockade of integrin $\alpha v \beta 6$ inhibits tumor progression in vivo by a transforming growth factor- $\beta$-regulated mechanism. Cancer research 2008, 68, (2), 561-570.

164. Bates, R. C.; Bellovin, D. I.; Brown, C.; Maynard, E.; Wu, B.; Kawakatsu, H.; Sheppard, D.; Oettgen, P.; Mercurio, A. M., Transcriptional activation of integrin $\beta 6$ during the epithelialmesenchymal transition defines a novel prognostic indicator of aggressive colon carcinoma. The Journal of clinical investigation 2005, 115, (2), 339-347.

165. Galliher, A. J.; Schiemann, W. P., $\beta 3$ integrin and Src facilitate transforming growth factor- $\beta$ mediated induction of epithelial-mesenchymal transition in mammary epithelial cells. Breast cancer research 2006, 8, (4), R42. 
166. Galliher, A. J.; Schiemann, W. P., Beta3 integrin and Src facilitate transforming growth factorbeta mediated induction of epithelial-mesenchymal transition in mammary epithelial cells. Breast cancer research : BCR 2006, 8, (4), R42.

167. Brooks, P. C.; Montgomery, A. M.; Rosenfeld, M.; Reisfeld, R. A.; Hu, T.; Klier, G.; Cheresh, D. A., Integrin alpha $v$ beta 3 antagonists promote tumor regression by inducing apoptosis of angiogenic blood vessels. Cell 1994, 79, (7), 1157-64.

168. Lehmann, M.; Rabenandrasana, C.; Tamura, R.; Lissitzky, J. C.; Quaranta, V.; Pichon, J.; Marvaldi, J., A monoclonal antibody inhibits adhesion to fibronectin and vitronectin of a colon carcinoma cell line and recognizes the integrins alpha $v$ beta 3 , alpha $v$ beta 5 , and alpha v beta 6. Cancer Res 1994, 54, (8), 2102-7.

169. Varner, J. A., The role of vascular cell integrins alpha $v$ beta 3 and alpha $v$ beta 5 in angiogenesis. Exs 1997, 79, 361-90.

170. Hood, J. D.; Frausto, R.; Kiosses, W. B.; Schwartz, M. A.; Cheresh, D. A., Differential alphav integrin-mediated Ras-ERK signaling during two pathways of angiogenesis. J Cell Biol 2003, 162, (5), 933-43.

171. Bao, W.; Strömblad, S., Integrin alphav-mediated inactivation of p53 controls a MEK1dependent melanoma cell survival pathway in three-dimensional collagen. J Cell Biol 2004, 167, (4), 745-56.

172. Mahabeleshwar, G. H.; Feng, W.; Reddy, K.; Plow, E. F.; Byzova, T. V., Mechanisms of integrin-vascular endothelial growth factor receptor cross-activation in angiogenesis. Circulation research 2007, 101, (6), 570-80.

173. Reynolds, L. E.; Wyder, L.; Lively, J. C.; Taverna, D.; Robinson, S. D.; Huang, X.; Sheppard, D.; Hynes, R. O.; Hodivala-Dilke, K. M., Enhanced pathological angiogenesis in mice lacking beta3 integrin or beta3 and beta5 integrins. Nat Med 2002, 8, (1), 27-34.

174. Byzova, T. V.; Goldman, C. K.; Pampori, N.; Thomas, K. A.; Bett, A.; Shattil, S. J.; Plow, E. F., A mechanism for modulation of cellular responses to VEGF: activation of the integrins. Mol Cell 2000, 6, (4), 851-60.

175. De, S.; Razorenova, O.; McCabe, N. P.; O'Toole, T.; Qin, J.; Byzova, T. V., VEGF-integrin interplay controls tumor growth and vascularization. Proceedings of the National Academy of Sciences of the United States of America 2005, 102, (21), 7589-94.

176. Nikolopoulos, S. N.; Blaikie, P.; Yoshioka, T.; Guo, W.; Giancotti, F. G., Integrin beta4 signaling promotes tumor angiogenesis. Cancer Cell 2004, 6, (5), 471-83.

177. Cardones, A. R.; Murakami, T.; Hwang, S. T., CXCR4 enhances adhesion of B16 tumor cells to endothelial cells in vitro and in vivo via beta(1) integrin. Cancer Res 2003, 63, (20), 6751-7.

178. Engl, T.; Relja, B.; Marian, D.; Blumenberg, C.; Müller, I.; Beecken, W. D.; Jones, J.; Ringel, E. M.; Bereiter-Hahn, J.; Jonas, D.; Blaheta, R. A., CXCR4 chemokine receptor mediates prostate tumor cell adhesion through alpha5 and beta3 integrins. Neoplasia 2006, 8, (4), 290-301.

179. Sun, Y. X.; Fang, M.; Wang, J.; Cooper, C. R.; Pienta, K. J.; Taichman, R. S., Expression and activation of alpha $v$ beta 3 integrins by SDF-1/CXC12 increases the aggressiveness of prostate cancer cells. The Prostate 2007, 67, (1), 61-73.

180. Seguin, L.; Kato, S.; Franovic, A.; Camargo, M. F.; Lesperance, J.; Elliott, K. C.; Yebra, M.; Mielgo, A.; Lowy, A. M.; Husain, H., An integrin $\beta$ 3-KRAS-RalB complex drives tumour stemness and resistance to EGFR inhibition. Nature cell biology 2014, 16, (5), 457-468.

181. Sethi, T.; Rintoul, R. C.; Moore, S. M.; MacKinnon, A. C.; Salter, D.; Choo, C.; Chilvers, E. R.; Dransfield, I.; Donnelly, S. C.; Strieter, R., Extracellular matrix proteins protect small cell lung cancer cells against apoptosis: a mechanism for small cell lung cancer growth and drug resistance in vivo. Nature medicine 1999, 5, (6), 662-668.

182. Curley, G.; Blum, H.; Humphries, M., Integrin antagonists. Cellular and Molecular Life Sciences CMLS 1999, 56, (5-6), 427-441.

183. Shimaoka, M.; Springer, T. A., Therapeutic antagonists and conformational regulation of integrin function. Nature Reviews Drug Discovery 2003, 2, (9), 703-716. 
184. Scarborough, R. M.; Naughton, M. A.; Teng, W.; Rose, J.; Phillips, D.; Nannizzi, L.; Arfsten, A.; Campbell, A.; Charo, I., Design of potent and specific integrin antagonists. Peptide antagonists with high specificity for glycoprotein IIb-IIla. Journal of Biological Chemistry 1993, 268, (2), 1066-1073.

185. Beekman, K. W.; Colevas, A. D.; Cooney, K.; DiPaola, R.; Dunn, R. L.; Gross, M.; Keller, E. T.; Pienta, K. J.; Ryan, C. J.; Smith, D., Phase II evaluations of cilengitide in asymptomatic patients with androgen-independent prostate cancer: scientific rationale and study design. Clinical genitourinary cancer 2006, 4, (4), 299-302.

186. Nabors, L. B.; Mikkelsen, T.; Rosenfeld, S.; Hochberg, F.; Akella, N. S.; Fisher, J. D.; Cloud, G.; Zhang, Y.; Carson, K. A.; Wittemer, S. M., A phase I and correlative biology study of cilengitide in patients with recurrent malignant glioma. Journal of clinical oncology: official journal of the American Society of Clinical Oncology 2007, 25, (13).

187. MacDonald, T. J.; Stewart, C. F.; Kocak, M.; Goldman, S.; Ellenbogen, R. G.; Phillips, P.; Lafond, D.; Poussaint, T. Y.; Kieran, M. W.; Boyett, J. M., Phase I clinical trial of cilengitide in children with refractory brain tumors: Pediatric Brain Tumor Consortium Study PBTC-012. Journal of clinical oncology 2008, 26, (6), 919-924.

188. Reardon, D. A.; Fink, K. L.; Mikkelsen, T.; Cloughesy, T. F.; O'Neill, A.; Plotkin, S.; Glantz, M.; Ravin, P.; Raizer, J. J.; Rich, K. M., Randomized phase II study of cilengitide, an integrintargeting arginine-glycine-aspartic acid peptide, in recurrent glioblastoma multiforme. Journal of Clinical Oncology 2008, 26, (34), 5610-5617.

189. Brooks, P. C.; Strömblad, S.; Klemke, R.; Visscher, D.; Sarkar, F. H.; Cheresh, D. A., Antiintegrin alpha $v$ beta 3 blocks human breast cancer growth and angiogenesis in human skin. The Journal of clinical investigation 1995, 96, (4), 1815-1822.

190. Mulgrew, K.; Kinneer, K.; Yao, X.-T.; Ward, B. K.; Damschroder, M. M.; Walsh, B.; Mao, S.-Y.; Gao, C.; Kiener, P. A.; Coats, S., Direct targeting of $\alpha v \beta 3$ integrin on tumor cells with a monoclonal antibody, Abegrin ${ }^{\mathrm{TM}}$. Molecular cancer therapeutics 2006, 5, (12), 3122-3129.

191. Gramoun, A.; Shorey, S.; Bashutski, J. D.; Dixon, S. J.; Sims, S. M.; Heersche, J. N.; Manolson, M. F., Effects of Vitaxin ${ }^{\circledR}$, a novel therapeutic in trial for metastatic bone tumors, on osteoclast functions in vitro. Journal of Cellular Biochemistry 2007, 102, (2), 341-352.

192. Delbaldo, C.; Raymond, E.; Vera, K.; Hammershaimb, L.; Kaucic, K.; Lozahic, S.; Marty, M.; Faivre, S., Phase I and pharmacokinetic study of etaracizumab (Abegrin ${ }^{\mathrm{TM}}$ ), a humanized monoclonal antibody against $\alpha \vee \beta 3$ integrin receptor, in patients with advanced solid tumors. Investigational new drugs 2008, 26, (1), 35-43.

193. McNeel, D. G.; Eickhoff, J.; Lee, F. T.; King, D. M.; Alberti, D.; Thomas, J. P.; Friedl, A.; Kolesar, J.; Marnocha, R.; Volkman, J., Phase I trial of a monoclonal antibody specific for $\alpha v \beta 3$ integrin (MEDI-522) in patients with advanced malignancies, including an assessment of effect on tumor perfusion. Clinical Cancer Research 2005, 11, (21), 7851-7860.

194. Trikha, M.; Zhou, Z.; Nemeth, J. A.; Chen, Q.; Sharp, C.; Emmell, E.; Giles-Komar, J.; Nakada, M. T., CNTO 95, a fully human monoclonal antibody that inhibits $\alpha$ v integrins, has antitumor and antiangiogenic activity in vivo. International journal of cancer 2004, 110, (3), 326-335.

195. Chen, Q.; Manning, C. D.; Millar, H.; McCabe, F. L.; Ferrante, C.; Sharp, C.; Shahied-Arruda, L.; Doshi, P.; Nakada, M. T.; Anderson, G. M., CNTO 95, a fully human anti $\alpha$ vintegrin antibody, inhibits cell signaling, migration, invasion, and spontaneous metastasis of human breast cancer cells. Clinical \& experimental metastasis 2008, 25, (2), 139-148.

196. Odekon, L.; Frewin, M.; Del Vecchio, P.; Saba, T.; Gudewicz, P., Fibronectin fragments released from phorbol ester-stimulated pulmonary artery endothelial cell monolayers promote neutrophil chemotaxis. Immunology 1991, 74, (1), 114.

197. Legler, D. F.; Wiedle, G.; Ross, F. P.; Imhof, B. A., Superactivation of integrin $(\alpha) \vee(\beta) 3$ by low antagonist concentrations. Journal of cell science 2001, 114, (8), 1545-1553. 
198. Aznavoorian, S.; Stracke, M. L.; Krutzsch, H.; Schiffmann, E.; Liotta, L. A., Signal transduction for chemotaxis and haptotaxis by matrix molecules in tumor cells. The Journal of cell biology 1990, 110, (4), 1427-1438.

199. Ebos, J. M.; Lee, C. R.; Cruz-Munoz, W.; Bjarnason, G. A.; Christensen, J. G.; Kerbel, R. S., Accelerated metastasis after short-term treatment with a potent inhibitor of tumor angiogenesis. Cancer cell 2009, 15, (3), 232-239.

200. Pàez-Ribes, M.; Allen, E.; Hudock, J.; Takeda, T.; Okuyama, H.; Viñals, F.; Inoue, M.; Bergers, G.; Hanahan, D.; Casanovas, O., Antiangiogenic therapy elicits malignant progression of tumors to increased local invasion and distant metastasis. Cancer cell 2009, 15, (3), 220-231.

201. Kanda, R.; Kawahara, A.; Watari, K.; Murakami, Y.; Sonoda, K.; Maeda, M.; Fujita, H.; Kage, M.; Uramoto, H.; Costa, C., Erlotinib resistance in lung cancer cells mediated by integrin B1/Src/Akt-driven bypass signaling. Cancer research 2013, 73, (20), 6243-6253.

202. Eke, I.; Zscheppang, K.; Dickreuter, E.; Hickmann, L.; Mazzeo, E.; Unger, K.; Krause, M.; Cordes, N., Simultaneous $\beta 1$ integrin-EGFR targeting and radiosensitization of human head and neck cancer. JNCl: Journal of the National Cancer Institute 2015, 107, (2).

203. Hirata, E.; Girotti, M. R.; Viros, A.; Hooper, S.; Spencer-Dene, B.; Matsuda, M.; Larkin, J.; Marais, R.; Sahai, E., Intravital imaging reveals how BRAF inhibition generates drug-tolerant microenvironments with high integrin $\beta 1 / F A K$ signaling. Cancer cell 2015, 27, (4), 574-588.

204. Tchaicha, J. H.; Reyes, S. B.; Shin, J.; Hossain, M. G.; Lang, F. F.; McCarty, J. H., Glioblastoma angiogenesis and tumor cell invasiveness are differentially regulated by $\beta 8$ integrin. Cancer research 2011, 71, (20), 6371-6381.

205. Gladson, C. L., Expression of integrin $\alpha v \beta 3$ in small blood vessels of glioblastoma tumors. Journal of Neuropathology \& Experimental Neurology 1996, 55, (11), 1143-1149.

206. Giovanna, M.; Kaye, A. H., Integrins: molecular determinants of glioma invasion. Journal of clinical neuroscience 2007, 14, (11), 1041-1048.

207. Giatromanolaki, A.; Sivridis, E.; Koukourakis, M. I., Tumour angiogenesis: vascular growth and survival. Apmis 2004, 112, (7-8), 431-440.

208. MacDonald, T. J.; Taga, T.; Shimada, H.; Tabrizi, P.; Zlokovic, B. V.; Cheresh, D. A.; Laug, W. E., Preferential susceptibility of brain tumors to the antiangiogenic effects of an alpha(v) integrin antagonist. Neurosurgery 2001, 48, (1), 151-7.

209. Yamada, S.; Bu, X. Y.; Khankaldyyan, V.; Gonzales-Gomez, I.; McComb, J. G.; Laug, W. E., Effect of the angiogenesis inhibitor Cilengitide (EMD 121974) on glioblastoma growth in nude mice. Neurosurgery 2006, 59, (6), 1304-12; discussion 1312.

210. Park, C. C.; Zhang, H.; Pallavicini, M.; Gray, J. W.; Baehner, F.; Park, C. J.; Bissell, M. J., $\beta 1$ integrin inhibitory antibody induces apoptosis of breast cancer cells, inhibits growth, and distinguishes malignant from normal phenotype in three dimensional cultures and in vivo. Cancer research 2006, 66, (3), 1526-1535.

211. Bhaskar, V.; Fox, M.; Breinberg, D.; Wong, M. H.; Wales, P. E.; Rhodes, S.; DuBridge, R. B.; Ramakrishnan, V., Volociximab, a chimeric integrin alpha5beta1 antibody, inhibits the growth of VX2 tumors in rabbits. Investigational new drugs 2008, 26, (1), 7-12.

212. Khalili, P.; Arakelian, A.; Chen, G.; Plunkett, M. L.; Beck, I.; Parry, G. C.; Doñate, F.; Shaw, D. E.; Mazar, A. P.; Rabbani, S. A., A non-RGD-based integrin binding peptide (ATN-161) blocks breast cancer growth and metastasis in vivo. Molecular cancer therapeutics 2006, 5, (9), 2271-2280.

213. Stoeltzing, O.; Liu, W.; Reinmuth, N.; Fan, F.; Parry, G. C.; Parikh, A. A.; McCarty, M. F.; Bucana, C. D.; Mazar, A. P.; Ellis, L. M., Inhibition of integrin $\alpha 5 \beta 1$ function with a small peptide (ATN-161) plus continuous 5-FU infusion reduces colorectal liver metastases and improves survival in mice. International journal of cancer 2003, 104, (4), 496-503.

214. Harms, J. F.; Welch, D. R.; Samant, R. S.; Shevde, L. A.; Miele, M. E.; Babu, G. R.; Goldberg, S. F.; Gilman, V. R.; Sosnowski, D. M.; Campo, D. A., A small molecule antagonist of the $\alpha \vee \beta 3$ 
integrin suppresses MDA-MB-435 skeletal metastasis. Clinical \& experimental metastasis 2004, 21, (2), 119-128.

215. Zhao, Y.; Bachelier, R.; Treilleux, I.; Pujuguet, P.; Peyruchaud, O.; Baron, R.; Clément-Lacroix, P.; Clézardin, P., Tumor $\alpha v \beta 3$ integrin is a therapeutic target for breast cancer bone metastases. Cancer research 2007, 67, (12), 5821-5830.

216. Shannon, K. E.; Keene, J. L.; Settle, S. L.; Duffin, T. D.; Nickols, M. A.; Westlin, M.; Schroeter, S.; Ruminski, P. G.; Griggs, D. W., Anti-metastatic properties of RGD-peptidomimetic agents S137 and S247. Clinical \& experimental metastasis 2004, 21, (2), 129-138.

217. Cai, W.; Wu, Y.; Chen, K.; Cao, Q.; Tice, D. A.; Chen, X., In vitro and in vivo characterization of $64 \mathrm{Cu}$-labeled AbegrinTM, a humanized monoclonal antibody against integrin $\alpha \mathrm{v} \beta 3$. Cancer research 2006, 66, (19), 9673-9681.

218. Leong-Poi, H.; Christiansen, J.; Klibanov, A. L.; Kaul, S.; Lindner, J. R., Noninvasive assessment of angiogenesis by ultrasound and microbubbles targeted to av-integrins. Circulation 2003, 107, (3), 455-460.

219. Chen, X.; Park, R.; Hou, Y.; Khankaldyyan, V.; Gonzales-Gomez, I.; Tohme, M.; Bading, J. R.; Laug, W. E.; Conti, P. S., MicroPET imaging of brain tumor angiogenesis with 18 F-labeled PEGylated RGD peptide. European journal of nuclear medicine and molecular imaging 2004, 31, (8), 1081-1089.

220. Murphy, E. A.; Majeti, B. K.; Barnes, L. A.; Makale, M.; Weis, S. M.; Lutu-Fuga, K.; Wrasidlo, W.; Cheresh, D. A., Nanoparticle-mediated drug delivery to tumor vasculature suppresses metastasis. Proceedings of the National Academy of Sciences 2008, 105, (27), 9343-9348. 